\title{
ilyilçe Milli Eğitim Müdürlükleri Denetim Rehberinin Yasal Belgeler ve Alanyazın Temelinde Incelenmesi
}

\author{
Dr. Özden Ölmez Ceylan \\ Milli Eğitim Bakanlı̆̆ \\ olmezozden@gmail.com
}

\author{
Erhan Algam (Y.L.Öğr.) \\ Özel Kocatürk ilkögrretim Okulu \\ erhanalg@yahoo.com
}

\begin{abstract}
Özet:
Bu araştırmanın amacı IVillçe Milli Eğitim Müdürlükleri Rehberlik ve Denetim Rehberini yasal belgeler ile alanyazın temelinde incelemek, elde edilen bulgular doğrultusunda öneriler geliştirmektir. Araştırmanın problemine uygun olarak nitel araştırma temelinde belge (doküman) inceleme tekniği kullanılmıştır. Bu bağlamda araştırmanın çalışma dokümanını "il/ilçe Milli Eğitim Müdürlükleri Rehberlik ve Denetim Rehberi" ile ilgili alan yazında 2010-2020 yılları arasında yapılan araştırmalar, yayınlanan makaleler, yüksek lisans / doktora tezleri ve yasal mevzuatlar oluşturmaktadır. Toplanan verilerin çözümlenmesinde içerik analizinden yararlanılmıştır. Araştırmanın sonuçlarına göre; rehberin genel olarak yasal belgeler temelinde tutarlıık gösterdiği, ancak bir kısmının yasal dayanaklara göre güncel olmadığı veya yürürlükten kaldırıldığı tespit edilmiştir. Alan-yazın temeli incelenme neticesinde ise rehberin genelde alanyazınla tutarlulı gösterdiği ancak rehberdeki ilgili maddeler alanyazına gönderme yapılmadığı sonuçlar arasında yer almaktadır. Bu bulgular temelinde kolay ulaşllabilmesi için rehberde yer alan yasal belgelerin dijital ortamda tek bir internet adresinde toplanması ve müfettişlere ulaştırılması için merkez teşkilatta görevli bir birim ya da uzman görevlendirilmesi, güncel tutmak adına rehberle ilgili maarif müfettişlerinden oluşan bir çalışma kurulu oluşturulması, rehberin alanyazın temelinde hazırlanması ve kontrolünün sağlanması amacıyla akademisyenlerden oluşan bir bilim kurulu oluşturulması çalışma bağlamında getirilen önerilerden bazılarıdır.
\end{abstract}

Keywords: Rehberlik ve denetim rehberi, il/ilçe milli eğitim müdürlükleri, Maarif müfettişi.

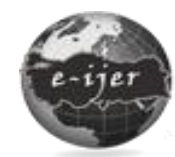

E-Uluslararası Eğitim Araştırmaları Dergisi, Cilt: 11, Sayı: 3, 20, ss.179-198

DOI: $\operatorname{xxxxxxx}$

Gönderim : $X X . X X . X X X X$ Revizyon 1 (varsa): $x x . x x . x x x x$ Kabul : $x x . X x . X x x x$

\section{Önerilen Atıf}

Ölmez Ceylan, Ö. \&. Algam, E. (2020). III/ilçe Milli Eğitim Müdürlükleri Denetim Rehberinin Yasal Belgeler ve Alanyazın Temelinde İncelenmesi, E-Uluslararası Eğitim Araştırmaları Dergisi, Cilt: 11, Sayı: 3, 2020, ss. 179-198, DOI: xxxx 


\section{Giriş}

Toplumların gelişmişlik düzeyini etkileyen temel unsurlardan biri eğitimin niteliğidir. Eğitim niteliğinin artırılabilmesi için sistemin bileşenlerinin verimli çalışmasının sağlanması gerekmektedir. Bu noktada sistemin işleyişinin sağlıklı bir şekilde sürdürülebilmesi nitelikli bir denetim ihtiyacını ortaya çıkarmaktadır. Denetimin hangi yeterliliklere sahip bireylerce ve hangi yolla yapılacağı da uluslararası standartlara ulaşılabilmesi noktasında önem taşımaktadır. Denetmen seçme ve atama kriterlerinin yetersizliği, denetmenlerin sık yer değiştirmesi, denetmenlerin soruşturma ve rehberlik görevlerinin bir arada olması, iş yüklerinin fazlalığı, aşırı bürokrasi ve politik baskı, zaman darlı̆̆ı, denetim ile ilgili mevzuatların yetersiz olması, sık değişmesi ve denetmenlere zamanında ulaşmaması gibi nedenler Maarif Müfettişleri Başkanlıkları arasında uygulama birliği eksikliğini ve standartlaşma yetersizliğini doğurmaktadır. Denetim sistemindeki bu sorunların üstesinden gelinmesi eğitimin niteliğini etkileyerek toplumsal gelişimi de sağlayacaktır. Okul, kurum ve birimlerde denetim ilke ve raporlama standartlarında birliğin sağlanması için denetim verilerinin ve personelin değerlendirilebilmesini sağlayacak bilimsel yöntem ve araçların geliştirilmesi, ölçütlerin saptanması ve denetmenlerin mesleki yeterliliğinin geliştirilmesi önem taşımaktadır. Alandaki denetimsel sorunların çözümünde standartlaşmayı sağlamak amacıyla MEB tarafından denetim rehberleri hazırlanmıştır. Denetim rehberlerine göre müfettişler arasında uygulama birliği sağlanmaya çalışılırken yasal alt yapı Anayasa, kanun, yönetmeliklere göre belirlenmiştir. Çünkü eğitim kurumlarının denetimi, eğitim sisteminde bir alt sistem olarak yer almaktadır. Denetim örgütsel, işlevsel ve yönetimsel bir zorunluluk olarak örgütsel eylemlerin belirlenen amaçlar doğrultusunda ilke ve kurallara uygun olup olmadığının anlaşılması sürecidir (Aydın, 2014). Eğitimde, denetim sisteminin ve sürecinin en önemli uygulayıcısı denetmenlerdir (Müfettişler). Eğitim denetimi ise eğitim örgütlerinin amaçlarının gerçekleşme derecesini saptamak, daha iyi sonuçlar elde edebilmek için önlem almak ve süreci geliştirmek çabalarının toplamıdır. Her örgüt gibi eğitim örgütleri de, varoluş nedeni olan amaçlarını gerçekleştirme durumunu sürekli olarak izlemek ve bilgi edinmek zorundadır (Aydın, 2008). Toprakçı 'ya (2008) göre eğitim denetimi yapılmış ya da yapılmakta olan eğitim faaliyetinin amaca uygun olarak gerçekleşip gerçekleşmediğini saptama sürecini inceleyen, açıklayan ve bu süreci öndeyileyen bilim dalıdır. Denetmenler, yasal çerçeveler doğrultusunda, bir yandan eğitim personeli ve kurum teftişi yaparken, diğer yandan suç unsuru oluşturabilecek durumlara ilişkin soruşturma görevlerini de yerine getirmektedirler.

Türk eğitim sisteminde denetim yapısı incelendiğinde; bir kamu kurumu olarak denetim ders denetiminden başlayarak sınıf denetimi, okul denetimi, il ve ilçe milli eğitim müdürlüklerinin (MEM) denetimi ve Bakanlık düzeyinde denetime kadar eğitim sisteminin her düzeyi için yapılandırılmıştır (Altunay, 2016). Bu bağlamda Türk eğitim sisteminin ülke yönetim anlayışı ile paralel biçimde merkezi bir yönetim anlayışına sahip olduğu görülmektedir. 1739 Sayılı Millî Eğitim Temel Kanunu'nun 56 Maddesinde de "Eğitim-ögretim hizmetinin, gözetim ve denetiminden Millı Eğitim Bakanlığı sorumludur." şeklinde ifade edilmiştir (Resmi Gazete, 1973). Milli Eğitim Bakanlığı; (1) merkez, (2) taşra ve (3) yurt dışı örgütü şeklinde örgütlenmektedir. Başaran'a (2006) göre Türk eğitim sisteminin örgüt yapısında aracı üst sistem: il ve ilçe milli eğitim müdürlükleridir. Milli Eğitim Bakanlığı merkez örgütü; bakanlık makamı ve merkez hizmet birimlerinden oluşmaktadır. Milli Eğitim Bakanlığının taşra örgütünde merkezdeki gibi bir yapılanma söz konusudur. Her ilde bir il milli eğitim müdürlüğü, her ilçede bir ilçe milli eğitim müdürlüğü bulunmaktadır. İlçe milli eğitim müdürlükleri il milli eğitim müdürlüğüne karşı sorumludur. Milli eğitim müdürlükleri mülki amirlere (illerde vali, ilçelerde kaymakam) bağlı olarak faaliyette bulunmaktadırlar (Akın, 2016). II milli eğitim müdürlükleri bünyesinde maarif müfettiş başkanlığı oluşturulmuştur (652 Sayılı KHK, 2011, Md.30). Maarif müfettişleri; il/ilçe milli eğitim müdürlükleri ile eğitim kurumlarının teftiş, denetim, rehberlik, işbaşında yetiştirme ve değerlendirme hizmetlerinin yürütülmesinden sorumludur (MEB III ve İlçe MEM Yönetmeliği, 2012, Md.7). Maarif Müfettişleri görevlerini yerine getirirken Milli Eğitim Bakanlığı Teftiş Kurulu Başkanlığı tarafından hazırlanan denetim rehberlerinden yararlanmaktadırlar. 
Yurt dışı alanyazınındaki eğitim ve denetim sistemleri incelendiğinde, gelişmekte olan ülkelerle, gelişmiş olan ülkelerin eğitim ve denetim sistemlerini doğrudan içeren yapısal ve işlevsel denetim rehberi çalışmalarına rastlanılmamıştır. Eğitim denetimi ve rehberi her ülkenin siyasal, sosyal, ekonomik, kültürel yapısı ve tarihi normlarına göre değişiklik gösterebilmektedir (Tezcan, 2015). Gelişmiş ülkelerin okullarında daha az merkeziyetçi, federal veya bölgesel okul özerkliğine dayanan nicelik değil nitelik göstergelerinin izlendiği, okulların kendi öz değerlendirme sistemlerini denetim için daha etkin kullandıkları tespit edilmiştir (Grauwe, 2008). Tonbul ve Baysülen 'e (2017) göre eğitimde başarılı olan ülkelerin dışarıdan müdahale eden denetim mekanizmaları bulunmakla birlikte, eksikleri saptama, değerlendirme ve buna dayalı olarak öğretmeni ve okulu geliştirme işinden sorumlu olan makam ağırlıklı olarak okul yönetimleridir. Gelişmekte olan ülkelerde eğitimin denetimi bölgesel müfettişler tarafından, idari denetim ise yerel hükümetlerin il/ilçe yetkilileri tarafından yapılmaktadır. İngiltere'de denetim görevi Eğitimde Standartlar Dairesi, yerel yönetim birimleri ve okullar tarafından paylaşılmaktadır (Süngü, 2002; Süngü, 2005). Türkiye'de olduğu gibi Fransa'da da merkeziyetçi bir yönetim anlayışı yer almaktadır ve merkezi yönetimin, eğitim kurumlarının denetimi üzerindeki etkisi dikkat çekmektedir. Fransa'da denetim yetkileri Milli Eğitim Bakanlığı'nda toplanmaktadır. Bunun yanında, milli eğitimin ilkeleri çerçevesinde, eğitim denetiminden sorumlu başka denetim birimleri de mevcuttur. Ulusal düzeyde görev yapan teftiş kurullarının yanı sıra bölgesel teftiş kurulları da bulunmaktadır (Sağlam ve Aydoğmuş, 2016).

Türk eğitim sisteminde denetim işlevinin kurumsal bir nitelik kazanması Osmanlı İmparatorluğu'nun son dönemleri ile birlikte ilan edilen Tanzimat'tan Modern Türkiye Cumhuriyeti'nin kuruluşuna kadar devlet eliyle, tam bir merkezi kontrolle yönetilecek şekilde yürütülmüştür. Türk eğitim sistemine ilişkin ilk yasal düzenleme 1869 yılında çıkarılan Maarif-i umumiye nizamnamesidir (Maarif-i Umumiye Nizamnamesi 5 bölüm ve 198 madde olarak 1869 yılında hazırlanmış ve eğitimin hemen hemen her konusu ile ilgilenmiştir.) Bu tüzük ile eğitim hakkı, eğitim yönetimi, öğretmen yetiştirme ve taşra teşkilatı ve sınav sistemleri gibi hususlar düzenlenmiştir. Türkiye'de bütün eğitim kurumları Tevhid-i Tedrisat Kanunu (1924) ile bugünkü adı ile Milli Eğitim Bakanlığı (MEB) çatısı altında toplanmışır. 1923-1935 yılları arasında "Maarif Vekâleti" olan MEB, 1989 yılından günümüze kadar "Milli Eğitim Bakanlığı" adıyla çalışmalarını sürdürmektedir. MEB'in teşkilat yapısı çeşitli yasal düzenlemelerle değişikliklere uğramış olup günümüzdeki son yapısı 14.9.2011 tarihinde yürürlüğe giren 652 sayılı Millî Eğitim Bakanlığının Teşkilat ve Görevleri Hakkında Kanun Hükmünde Kararname ile belirlenmiştir (652 Sayılı KHK, 2011, Md.2). Bu doğrultuda il ve ilçeler düzeyinde denetim görevi il/ilçe milli eğitim müdürlüklerine verilmiştir. II/ilçe milli eğitim müdürlüklerinin denetim emriyle yapılacak olan rehberlik ve denetim hizmetleri, Başkanlığın Bakanlık, Maarif Müfettişleri Başkanlıklarının ise Valilik Onay'ına dayalı olarak hazırladıkları ve ilgili maarif müfettişlerine verdikleri rehberlik ve denetimi işlevine ait görevlendirme talimatıyla yapılmaktadır. Bu talimat kapsamda rehberlik ve denetim grubundan sorumlu olan maarif müfettişi, denetim ve araştırma çalışmalarında işlerin zamanında ve düzenli bir şekilde yürütülmesinden sorumludur. Grubun yıllık rehberlik ve denetim faaliyet planı ve raporunu gruptaki müfettişlerle birlikte hazırlayarak maarif müfettişleri başkanlığına sunar.

iVilçe milli eğitim müdürlüklerinin tarihsel süreç içinde sorumluluk alanı ve kurumsallaşma süreci incelendiğinde görevlerini planlı ve sistemli bir şekilde yürütmesi gerek-liliği ortaya çıkmaktadır. II/ilçe milli eğitim müdürlüklerinin denetimin süreçleri doğrultusunda yapılan denetimlerin mevzuatla örtüşmesi, Maarif Müfettişleri Başkanlıkları arasında uygulama birliği ve standartlaşmayı sağlama, rehberlik ve denetim ilkelerinin uygulanması, denetçiler ve denetim sonuçlarının raporlanarak ilgili birim ve kişilere iletilmesinde bazı sorunlar olduğu tespit edilmiştir (Aypay, 2010, Gündüz ve Can, 2013; Sarpkaya, 2004). Öte yandan dünyada hızla değişen ve yenilenen şartlar, denetim anlayışındaki kurumsal değiş̧imler ve gelişmeler, rehberlik ve denetim esaslarının yeniden ele alınmasını ve düzenlenmesini zorunlu hale getirmiştir. Bu 
nedenle sorunların çözümüne ışık tutacak olan Teftiş Kurulu Başkanlığı́nın resmi web sayfasında yayımlanan, rehberlik ve denetim kılavuzlarından erişime açık olan "il/ilçe Milli Eğitim Müdürlükleri Rehberlik ve Denetim Rehberi"nin incelenmesi önem taşımaktadır. Bununla birlikte denetimle ilgili olarak kurumlarda yapılan uygulamalarda farklı stratejilerin ve yöntemlerin izlendiği görülmektedir. Denetimler sonrası verilen kararlara ilişkin birçok soruşturma açılmaktadır (Çelebi, Övür ve Eravcı, 2016). MEB'in denetimine tabi olan kurumlarda farklı strateji ve tekniklerden kaynaklı hukuksal sorunların üstesinden gelinebilmesi için eğitim denetiminde standart bir rehberin varlığı, yönetmeliklerde belirlenen denetim sürecinin daha bilimsel, sağlıklı, tutarlı ve verimli olmasını sağlayacaktır. Nitekim bürokrasi kuramı, bilimsel yönetim kuramı vb. klasik yönetim kuramlarında göreve ve kurumsal işleyişe ilişkin ilkeler, önermeler, genellemeler, kavramlar ve tanımların önemli olduğu vurgulanmaktadır (Miles, 2016). Örneğin bürokrasi kuramı; "örgütün iş ve işleyişindeki her faaliyetin yazılı belgeye aktarılması ve işleyişle tutarlı olması gerektiğini savunmaktadır." Rehberde maddelerin yasal belgelerle desteklenmesi ve denetim sürecinde yapılacakların açıklanması bu kuram temelinde ele alınabilir. "il/ilçe Milli Eğitim Müdürlükleri Rehberlik ve Denetim Rehberi'nin" hazırlanması bu doğrultuda bir çaba olarak değerlendirilebilir.

Alanyazında denetim ve rehber kavramını ayrı ayrı kapsayan ve birçok değişkeni içeren çalışmaların olduğu tespit edilmiştir. Bunlar daha çok Türkiye'de denetim ve rehberlikle ilgili çalışmalarda il/ilçe milli eğitim müfettişlerinin karşılaştıkları sorunlar ile denetmenlerinin öğretmenlere yönelik rehberlik rollerini yerine getirmeleri ilgili araştırmalar (Memişoğlu ve Sağır, 2008), Türk eğitim denetimi sisteminin diğer ülkelerin denetim sistemi ile karşılaştırılması (Demirkasımoğlu, 2011), rehberlik ve denetim çalışmaları (Şahin, 2017), ortaokul müdürlerinin öğretimsel denetime ilişkin görüşleri (Beytekin ve Tas, 2017), eğitim denetiminin niteliğinin geliştirilmesi, işlevsel ve yönetsel açıdan değişim çabaları (Gönülaçar, 2018), yasal belgeler temelinde Türkiye'deki eğitim yönetimi ve denetimi alanındaki uygulamalar (Toprakçı ve Kadı, 2014), kamu yararına çalışan derneklerin eğitim faaliyetlerinin yönetimi ve denetimi (Toprakçı ve Akçay, 2016), MEB Sayıştay denetim raporları (Toprakçı ve Bakır, 2019) gibi çeşitli araştırmaların alanyazında yapıldığı tespit edilmiştir. Ancak MEB tarafından hazırlanan denetim rehberlerini doğrudan inceleyen herhangi bir çalışmaya erişilememiştir. "Milli Eğitim Bakanlığı Teftiş Kurulu Başkanlığı Görev, Yetki, Sorumluluk ve Çalışma Esaslarına Dair Yönerge"nin 25. Maddesine göre Rehberlik ve Denetim Daire Başkanlığının görevlerinden birinin "Bakanlık, merkez, taşra ve yurtdışı teşkilatı ile okul, kurum ve personelin rehberlik ve denetimine ilişkin esasların ve rehberin hazırlanması, uygulanması ve geliştirilmesine ilişkin iş ve işlemleri yürütmek" olduğu görülmektedir. İlgili madde doğrultusunda denetim rehberinin geliştirilmesine vurgu yapıldığı görülmekte ve bu bağlamda rehberin güncel olması beklenmektedir. Rehberin geliştirilmesi ve güncel tutulması; ileriki dönemlerde rehberliği eğitim denetimi alanında kullanacak olan ve denetlenen kişileri aydınlatması, yol göstermesi ve alanyazına katkı sağlaması bakımından önem taşımaktadır. Bu bağlamda çalışmanın amacı MEB'in yayınladığı, "il / ilç̧e Millı̂ Eğitim Müdürlükleri Rehberlik ve Denetim Rehberi" dokümanının yurt içi yasal belgeler ve alanyazın temelinde tutarlı ve tutarsız yönlerini incelemek, elde edilen bulgular doğrultusunda öneriler geliştirmektir.

\section{YÖNTEM}

Bu bölümde araştırmanın modeli, verilerin elde edilme süreci ve analizinde kullanılan tekniklere yer verilmiştir.

Araştırmanın Modeli: Araştırmada denetim rehberinin gerçekçi ve bütüncül bir şekilde incelenmesi amacıyla nitel araştırma yapılmıştır. Yıldııım ve Şimşek 'e (2013) göre nitel araştırma modeli, gözlem, görüşme ve dokuman incelemesi gibi nitel veri toplama tekniklerinin kullanıldığı, olayların doğal ortamda gerçekçi ve bütüncül bir şekilde ortaya konmasına yönelik bir sürecin izlendiği araştırmadır. Araştırmada, nitel veri toplama tekniklerinden belge (doküman) incelemesi tekniği kullanılmıştır. Doküman incelemesi, araştırma kapsamında 
incelenen konuyla ilgili olgu ve olaylar hakkında bilgi içeren yazılı belgelerin analiz edilmesiyle verilerin sağlanmasıdır (Yıldırım ve Şimşek, 2016). Araştırmacı, araştırmanın konusuna bakarak hangi dokümanın önemli olduğunu ve veri kaynağı olarak neleri kullanılabileceğine karar vermesi gerekir. Doküman incelemesi için kişisel, kamu ve arşiv dokümanları kullanılabilir. Doküman incelemesi beş aşamadan meydana gelmektedir. Bu aşamalar sırasıyla; dokümanlara ulaşma, dokümanların orijinalliğini kontrol etme, dokümanları anlama, veriyi analiz etme ve kullanmadır (Yıldıım ve Şimşek, 2016). Denetim rehberi, bir kamu belgesi olarak maarif müfettişlerine denetimde yol göstermek, kurum denetiminde uygulama birliği ve standartlaştırmayı sağlamak ve sorunlu alanları önceliklendirerek denetim yapılmasını gerçekleştirmek amacıyla doküman incelemesinin aşamalarına göre analiz edilmiştir.

Çalışma Dokümanı: MEB Teftiş Kurulu Başkanlığı 2016 yılında resmi web sitesinde kurumların teftişine yönelik olarak 16 adet "rehberlik ve denetim rehberi" yayımlamıştır (tkb.meb.gov.tr). Bu rehberler maarif müfettişlerine denetimlerinde yol göstermek ve teftiş sürecinde uygulayacakları esasları belirtmek amacıyla hazırlanmıştır. Yayınlanan bu rehberlerden biri de "il / ilçe Millî Eğitim Müdürlükleri Rehberlik ve Denetim Rehberi" dokümanıdır. Bu dokümana MEB Teftiş Kurulu Başkanlığı'nın internet sitesi ortamında 24.04.2020 tarihinde ulaşımıştır. Söz konusu doküman yasal dayanak (kanun, yönetmelik, yönerge, genelge) ve alan yazın temelinde incelenmiştir. Ayrıca araştırmada alanyazında 2010-2020 yılları arasında eğitim denetimi ve rehberi ile ilgili yayınlanan makaleler, yüksek lisans / doktora tezlerinden (çevrim içi ortam; Google Akademik, Resmi siteler, Ege Üniversitesi Kütüphane ve Dokümantasyon Daire Başkanlığı Resmi Web sayfası, Google ve Yandex) yararlanılmıştır. Buna göre ulaşılan belgeler (rehber hariç olmak üzere) sınırlığında bir incelemenin gerçekleştiğini belirtmek gerekir. Bu durumda çalışma dokümanı olan denetim rehberi iki ana başıı altında incelenmiştir: 1) il / iliçe Millî Eğitim Müdürlükleri Rehberlik ve Denetim Rehberi'nin Yasal Belgelerle ilişkisi 2) II / İlçe Millî Eğitim Müdürlükleri Rehberlik ve Denetim Rehberi'nin alanyazınla ilişkisi. Bu ana başıılar altında yer alan ilgili maddeler ayrı ayrı ele alınarak analiz edilmiştir.

Verilerin Toplanması ve Analizi: Bu çalışmada nitel araştırma tekniklerinden belge (doküman) incelemesi ile toplanan verilerin çözümlenmesinde içerik analiz tekniği kullanılmıştır. İçerik analizinde temel amaç, toplanan verileri açıklayabilecek kavramlara ve ilişkilere ulaşmaktır. Özetlenen ve yorumlanan veriler içerik analizinde daha derin bir işleme tabi tutulur (Yıldırım ve Şimşek, 2016). İçerik analizi; verilerin kodlanması, temaların bulunması, kodların ve temaların düzenlenmesi, bulguların tanımlanması ve yorumlanması aşamalarından oluşmaktadır (Yıldırım ve Şimşek, 2013). Bu bağlamda yasal belgeler ve alanyazın temel alınarak rehbere ilişkin iki aşamada içerik analizi yapılmıştır. Illk aşamada rehberin kendisi ve rehberin gönderme yaptığı yasal belgeler ile ilişkisi incelenmiştir.

İkinci aşamada ise araştırmacılar rehberin alanyazın ile ilişkisinin analiz işlemi için çevrim içi ortam, gerçek ve sanal kütüphaneleri yardımcı araçları ile " alanyazınsal zihin çerçeveleri (alanyazında ustalık) " sınırlıı̆ını aşkınlık seviyesine gelinceye kadar okumalar yapmışlar ve bu okumalar sonucunda belirlenen temalar, kategoriler ve kodlara ulaşmışlardır. Bu süreçte çelişkiye düşülen durumlarda kaynaklara, meslektaş teyidine, uzman görüşüne başvurulmuştur.

Illk aşamada içerik analizinde rehber yasal belgeler temel alınarak incelenmiş; tema, kategori ve kodlar oluşturulmuş; ikinci aşamada ise alanyazın temel alınarak rehber incelenmiş; tema, kategori ve kodlar oluşturulmuştur. Bu aşamalar neticesinde "Denetim Rehberinin Yasal belgelerle Tutarlı̆̆ı̆ı", "Denetim Rehberinin Yasal Belgelerle Tutarsızlığı", "Denetim Rehberinin Alanyazınla Tutarlıı̆ı" ve "Denetim Rehberinin Alanyazınla Tutarsızlığı" kategorileri ortaya çıkmıştır. Bu doğrultuda bu kategoriler altında "Yasal dayanağa uygunluk", "Yasal dayanak belirsizliği", "Yasal dayanağa göre eksik ifade edilme", "Yasal dayanağa göre fazla ifade edilme", "Yasal dayanağa internet ortamında ulaşamama", "ilgili yasal dayanaklara eksik gönderme", "Yasal dayanağa göre güncel olmama", "Alanyazına uygunluk", "Alanyazına atıfsızlı", "Alanyazın içerik eksikliği", "Alanyazına aykırılık" ve "Alanyazınla kavram tutarsızlığı" şeklinde kodlar yer almaktadır İçerik analizi neticesinde elde edilen verilerin bulguya dönüştürülerek daha iyi 
anlaşılması amacıyla veriler yüzde dağılımı ve sayılar şekline ifade edilmiştir. Bu bulgular ışığında temalar oluşturulmuş temaya yönelik alıntılar ve yorumlar eklenerek ayrıntılı açıklamalar yapılmıştır. Yapılan içerik analizlerine birkaç örnek Tablo 1'de verilmektedir.

Tablo 1: il / Ilç̧e Millî Eğitim Müdürlükleri Rehberlik ve Denetim Rehberi içerik analizi örnekleri

\begin{tabular}{|c|c|c|c|}
\hline Tema & $\begin{array}{l}\text { Kateg } \\
\text { ori }\end{array}$ & Kod & Kodları biçimleyen ifadeler /Gönderme yapılan yasal belge/ilgili madde \\
\hline \multirow{4}{*}{ 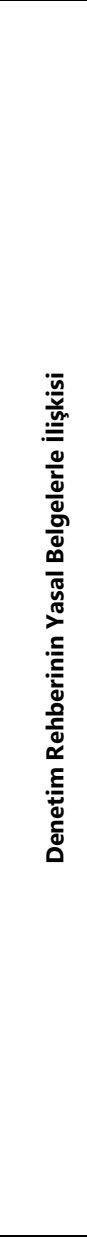 } & \multirow{2}{*}{ 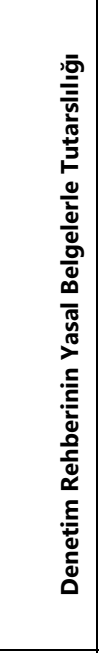 } & \multirow{2}{*}{ 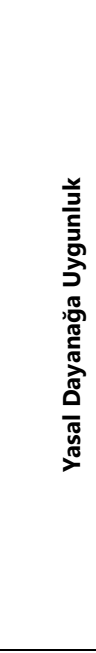 } & $\begin{array}{l}\text { Rehberde: } \\
\text { 2. EĞiTiM ÖĞRETIM FAALIYETLERi } \\
\text { 2.2. Öğretim Etkinlikleri } \\
\text { 2.2. 7. Hayat Boyu Öğrenme } \\
\text { 1. Örgün eğitim alamayan bireylerin bilgi ve becerilerini geliştirici tedbirlerin alınması 2. Hayat boyu } \\
\text { öğrenmenin imkân, fırsat, kapsam ve yöntemlerinin geliştirilmesi 3. Yetişkinlere yönelik yaygın meslekî eğitim } \\
\text { verilmesinin sağlanması (...)" } \\
\text { Yasal Belgedeki Karşılığı: } \\
\text { MEB ve İlçe Milli Eğitim Müdürlükleri Yönetmeliği hayat boyu öğrenme hizmetleri madde } 15 \text { "a) Örgün } \\
\text { eğitim alamayan bireylerin bilgi ve becerilerini geliştirici tedbirler almak, b) Hayat boyu öğrenmenin imkân, } \\
\text { fırsat, kapsam ve yöntemlerini geliştirmek, c) Yetişkinlere yönelik yaygın meslekî eğitim verilmesini sağlamak } \\
\text { (...) (Resmî Gazete 2012, S: 28471) }\end{array}$ \\
\hline & & & $\begin{array}{l}\text { Rehberdeki ifadeler ile yasal dayanaktaki ifadeler karşılaştırılığında. "Eğitim Öğretim faaliyetleri" ana başlığı } \\
\text { altında, "Öğretim Etkinlikleri" kapsamında yer alan, "hayat boyu öğrenme" maddelerinin, MEB ve İlçe Milli } \\
\text { Eğitim Müdürlükleri Yönetmeliği hayat boyu öğrenme hizmetleri madde 15' e gönderme yaptığı tespit } \\
\text { edilmiştir. Illgili maddeye internet ortamında ulaşılmıştır (Resmî Gazete 2012, S: 28471). İlgili yönetmeliğin } \\
\text { maddeleri, rehberdeki maddelerle karşılaştıııdığında; maddelerin bire bir örtüştüğü tespit edilmiştir. } \\
\text { Bundan dolayı bu madde rehberin içerik analizi neticesinde yasal belgeler temelinde tutarlıı̆ını } \\
\text { gösterdiğinden dolayı tutarlılık kategorisi başlığı altında "Yasal Dayanağa Uygunluk" kodu ile ifade } \\
\text { edilmiştir. }\end{array}$ \\
\hline & \multirow{2}{*}{ 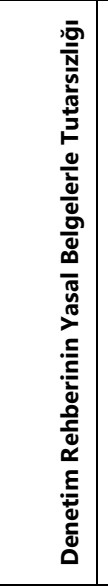 } & \multirow{2}{*}{ 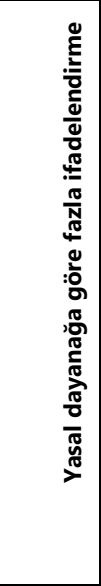 } & $\begin{array}{l}\text { Rehberde } \\
\text { II. REHBERLIK ve DENETIM RAPORLAMA STANDARTLARI } \\
\text { 1. RAPOR YAZIM ILKELERI } \\
\text { "Doğruluk; Raporun gerçeklere dayanmasını ifade eder. Tarafsızlık; Gözlem, tespit, sonuç ve önerilerin } \\
\text { gerçeğe dayalı, çarpıtmadan uzak ve önyargısız olarak ortaya konulmasını ifade eder. Açılık; Raporun yeterli } \\
\text { bilgiyi anlaşılır şekilde ortaya koymasını ifade eder. Ölçülebilirlik; Raporda getirilen tekliflerin, önerilerin, } \\
\text { yorumların karşılaştırılabilir ve rakamsal olarak ortaya konulmasını ifade eder.(...)" şeklinde belirtilmiştir. } \\
\text { Yasal Belgedeki Karşılığı } \\
\text { MEB Teftiş Kurulu yönetmeliğinde "Raporlar kısa, açık, kolay anlaşılır, tekrara yer vermeyecek tarzda ve } \\
\text { yazım kurallarına uygun bir üslupla yazılır. Raporlarda ulaşılan görüş, kanaat ve sonuç ile teklifler tereddüt } \\
\text { oluşturmayacak nitelikte, belgelere ve mevzuata dayandırılarak açıklanır (MEB Teftiş Kurulu Yönetmeliği } \\
\text { 2017, m.53/1-2)." }\end{array}$ \\
\hline & & & $\begin{array}{l}\text { Rehberde bölüm II "REHBERLiK ve DENETIM RAPORLAMA STANDARTLARI " altında yer alan "1. RAPOR } \\
\text { YAZIM ILKELERI" ile ilgili maddeler MEB Teftiş Kurulu Yönetmeliği'ndeki maddeler ile } \\
\text { karşış̧ı̧ııldığında.(MEB Teftiş Kurulu Yönetmeliği 2017, m.53/1-2) Rehberde yer alan ifadelerin yasal } \\
\text { dayanağa göre daha kapsamlı olduğu ve daha fazla detaylara yer verildiği tespit edilmiştir. Bu bağlamda } \\
\text { ilgili madde tutarsızlık kategorisi başlığı altında "yasal dayanağa göre fazla ifadelendirme" kodu içersinde } \\
\text { yer almıştır. }\end{array}$ \\
\hline \multirow{4}{*}{ 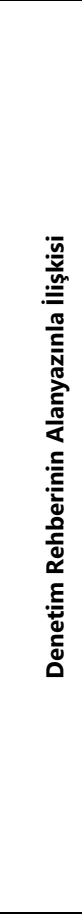 } & \multirow{2}{*}{ 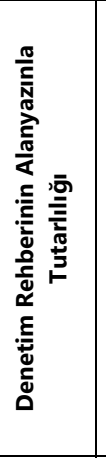 } & \multirow[t]{2}{*}{$\frac{\text { 兰 }}{\text { D̆ }}$} & $\begin{array}{l}\text { Rehberde: } \\
\text { Kullanıcı grubların oluşturulması ve yetkilendirilmesi } \\
\text { MEBBis altında bulunan tüm modüllere bilgi girişinin eğitim paydaşları tarafından zamanında doğru şekilde } \\
\text { yapılması, güncelleme işlemlerinin anlık olarak yapılması ve ilgili modüller(...)" } \\
\text { Alanyazında: } \\
\text { Ayral (2007) göre teknolojinin genellikle zorunlu rutin işlerde kullanıldığına vurgu yaparak E-Okul ve } \\
\text { MEBBiS veri tabanlarının devam-takip, listeler alma, kayıt, güncelleme, nakil işlemlerini yapma gibi } \\
\text { işlemlerde kullanıldığına dikkat çekmektedir. Akbaba ve Altun (2000) araştırmalarında okul yöneticilerinin } \\
\text { bilgi iletişim teknolojilerini çoğunlukla resmi yazışma, kayıtların tutulması ve kırtasiyeciliğin azaltılması } \\
\text { amacıyla kullandıkları sonucuna varmışlardır. }\end{array}$ \\
\hline & & & $\begin{array}{l}\text { Rehberde ifade edilen MEBBiS veri tabanında bulunan tüm modüllere ait bilgi girişinin zamanında doğru } \\
\text { şekilde yapılması ve güncelleme, devam-takip, listeler alma, kayıt, nakil işlemleri ile ilgili olarak alanyazında } \\
\text { da atıfta bulunulduğu tespit edilmiştir. Bu durumda ilgili ifade denetim rehberinin alanyazınla tutarlığı } \\
\text { kategorisi altında "alanyazına göre uygunluk" kodu içerisinde yer almıştır. }\end{array}$ \\
\hline & \multirow[t]{2}{*}{ 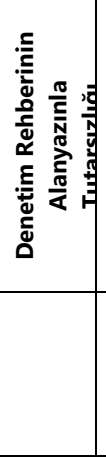 } & \multirow[t]{2}{*}{ 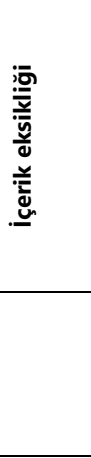 } & $\begin{array}{l}\text { Rehberde } \\
\text { AMAÇ, KAPSAM, DAYANAK VE TANIMLAR } \\
\text { Denetim rehberinin amacı "MEB bağlı il/ilçe milli eğitim müdürlüklerinin denetiminde uygulanacak esasları } \\
\text { belirlemektir." şeklinde ifade edilmiştir. } \\
\text { Alanyazında Açılaması } \\
\quad \text { Oysa denetim rehberinin amaç cümlesi alanyazın temelli geniş bir çerçevede tanımlanabilirdi. } \\
\text { Örneğin alanyazında Feyereisen, Fiorino ve Nowak'a göre, (1970:13) denetimin amacı okullardaki öğretme } \\
\text { ve öğrenme konularında program düzenleme ve karar vermedir. Denetim, eğitim ve öğretim } \\
\text { programlarının hem niteliksel hem niceliksel boyutları üzerinde durmaktadır. }\end{array}$ \\
\hline & & & $\begin{array}{l}\text { Rehberde denetimin amacı çok kısıtlı olarak tanımlanmıştır. Illgili madde alanyazında eğitim ve öğretim } \\
\text { programlarının hem niteliksel hem niceliksel boyutları üzerinden tanımlanmıştır. Bu durum alanyazında } \\
\text { mevcut olan ifadelerin rehberde eksik olması, rehberin alanyazın temelli içerik eksikliği tutarsızlığını } \\
\text { göstermektedir. Alanyazında olup rehberde eksik olan ifadeler bu kod altında belirtilmiştir. Bu bağlamda } \\
\text { ilgili ifade alanyazınla tutarsızlık kategorisi başlığı altında "içerik eksikliği" kodu içerisinde yer almıştır. }\end{array}$ \\
\hline
\end{tabular}


Tablo 1'de görüldüğü üzere veri analiz sürecinin daha iyi anlaşılması için denetim rehberinde yer alan "Denetim Rehberinin Yasal belgelerle Tutarlı̆ı̆ı", "Denetim Rehberinin Yasal Belgelerle Tutarsızlı̆ıı", "Denetim Rehberinin Alanyazınla Tutarlı̆ı̆ı" ve "Denetim Rehberinin Alanyazınla Tutarsızlığı" kategorilerine ait uygun kodlar için ayrı ayrı örnekler verilmiştir.

Geçerlilik ve Güvenilirlik: Çalışmanın geçerlilik ve güvenilirliğini sağlamak için uzman incelemesi ve meslektaş teyidi alınarak verilerin iç geçerliliği (inandırıcılığı) sağlanmıştır (Büyüköztürk, 2018). Yıldırım ve Şimşek'in (2016) ifade ettiği gibi doğru bilgiye ulaşma konusunda gereken önlemlerin alınması (geçerlilik) araştırma sürecini, verileri açık ve ayrıntılı bir biçimde, yani bir başka araştırmacının değerlendirmesine olanak verecek bir şekilde tanımlanması (güvenilirlik), nitel araştırmanın karşılaması gereken önemli beklentilerdir. Bu bağlamda MEB Teftiş Kurulu Başkanlığının farklı kurumlarına yönelik "rehberlik ve denetim rehberleri" alanda uzman kişiler ile birlikte Eğitim Fakültesi, Eğitim Bilimleri Bölümü, Eğitim Yönetimi, Teftişi, Planlaması ve Ekonomisi Anabilim Dalı bölümünde görev yapan bir öğretim üyesi tarafından incelenmiştir. Ayrıca denetim rehberlerinin incelenmesi ile ilgili olarak ekip üyelerinin toplantılar vesilesi ile bir araya geldiklerinde fikir alışverişinde bulunmaları geçerliliğe ve güvenilirliğe katkı sağlamıştır. Rehberlerin incelenmesi için; katılımcımlar, internet ortamında belirlenen gün ve saatte canlı toplantı araçları üzerinden, her hafta olmak üzere toplam 12 hafta süresince bir araya gelmişlerdir. Yapılan toplantılar tekrar izlenebilmek maksadıyla kaydedilmiştir. Bu toplantılarda uzman görüşü alınması ve geribildirim sağlanması amacıyla eğitim bilimi ve denetimi alanına yayınları olan alanında yetkin bir akademisyen ile bir maarif müfettişte yer almıştır. Toplantılarda öncelikle rehberlerin hangi yönlerden incelenebileceği üzerinde çalışmalar yapılmıştır. Daha sonra rehberin yasal dayanak ve alanyazın temelinde incelenmesi ve buna bağlı olarak içerik analizlerinin yapılması temaların, kategorilerin ve kodların oluşturulması süreçleri üzerinde yoğunlaşılmıştır. Çalışma süreçlerinde belirlenen temalar, kategoriler ve kodlar karşılaştırılarak benzer ve farklı yönler üzerinde durulmuştur. Anlaşmazlığa düşülen noktalar üzerinde tartışmalar yapılmış ve fikir birliği sağlanıncaya dek toplantılar sürdürülmüştür. Çözüme kavuşturulan bir anlaşmazlık örneği vermek gerekirse Anayasa'nın 42 inci maddesinde, "Eğitim ve öğretim, Atatürk ilkeleri ve inkılâpları doğrultusunda, çağdaş bilim ve eğitim esaslarına göre, Devletin gözetimi ve denetimi altında yapılır. Bu esaslara aykırı eğitim ve ögretim yerleri açlamaz" şeklinde ifade edilmiştir. Rehberde ise ilgili madde "Eğitim ve öğretim, Atatürk ilkeleri ve inkılâpları doğrultusunda, çağdaş bilim ve eğitim esaslarına göre, Devletin gözetimi ve denetimi altında yapılır." şeklinde ifade edilmiştir. "(...) Bu esaslara aykırı eğitim ve öğretim yerleri açılamaz" ifadesinin rehberde yer almaması yasal dayanak teması altında tutarsızlık kategorisi ile ifade edilmiş ve yasal dayanağa eksik gönderme koduyla belirtilmiştir. Ancak konuyla ilgili olarak canlı toplantılarda yapılan tartışmalar neticesinde; "il/ilçe Milli Eğitim Müdürlükleri Rehberlik ve Denetim Rehberi'nin" maarif müfettişlerine denetimlerde yol göstermek amacıyla düzenlendiği ifade edilmiştir. Ancak söz konusu maddeyle ilgili olarak canlı toplantıda katılımcıların ve özellikle maarif müfettişinde bu konuda görüşü alınmıştır. Sonuçta yasa gereği maarif müfettişlerinin eğitim ve öğretim kurumu açma, kapama yetkisinin olmadığı ancak denetim sonucunda gördüğü eksiklikleri MEB 'in rapor halinde sunabileceği ve MEB'in ilgili makamlarınca gerekli tedbirlerin alınabileceği belirtilmiştir. Bu nedenle burada yasal olarak eksik bir ifadenin söz konusu olamayacağı konusunda katılımcılar arasında bir mutabakat sağlanmıştır. Bu bağlamda ilgili madde "yasal dayanağa eksik gönderme" kodu altından çıkarılmış olup rehberde doğru ifade edildiği sonucuna ulaşılmıştır.

Rehberin içerdiği bilgiler MEB'in anayasa, kanunları, tüzükleri, yönetmelikleri, genelge ve yönergeleri ile de desteklenmiştir. Ayrıca araştırmacının araştırmada toplanan verilerin inandırıcılığına, görüş birliğine dayalı olarak analizine, sonuç ve süreçlerine yansız, eleştirel bir gözle bakması, ayrıntıı bir şekilde raporlaştırılması, araştırmanın geçerliliğini ve güvenirliliğini sağlamıştır. Son toplantının ardından çalışma alanında uzman akademisyenlere gönderilmiş ve onların görüşleri de çalışmaya dâhil edilmiştir. Ayrıca ihtiyaç olması durumunda araştırmaya 
temel olan ham veriler paylaşılmak maksadıyla veya başka bir araştırmada karşılaştırma yapılabilmek amacıyla muhafaza edilmiştir. Böylece araştırmanın dış güvenilirliği artııılıştır.

\section{BULGULAR VE YORUM}

Bu bölümde "il/ilçe Milli Eğitim Müdürlükleri Rehberlik ve Denetim Rehberi'nin" yasal belgeler ile alan yazın temelinde incelenmesi neticesinde ortaya çıkan tema, kategori ve kodların dağılımına, bulguları destekleyen alıntılara ve bu bulguların alan yazın temelli yorumlanmasına yer verilmiştir.

\section{1. il/ilçe Milli Eğitim Müdürlükleri Rehberlik ve Denetim Rehberinin Yasal Belgeler Temelinde İncelenmesi}

II/Ilç̧e Milli Eğitim Müdürlükleri Rehberlik ve Denetim Rehberi'nin yasal belgeler temelli incelendiğinde denetim rehberinin yasal belgelerle ilişkisi teması altında denetim rehberinin yasal belgeler ile tutarııı̆ı ve tutarsızığı olmak üzere iki kategori ortaya çıkmaktadır. Bu kategoriler kendi içinde kodlardan oluşmaktadır. Bu kodlar doğrultusunda elde edilen bulgulara Tablo 2'de yer verilmiştir.

Tablo 2: Denetim Rehberinin Yasal Belgelerle ilişkisi" teması altında ortaya çıkan kategori ve kodların dağılımı

\begin{tabular}{|c|c|c|c|}
\hline TEMA & KATEGORILER & KODLAR & $\mathbf{f}$ \\
\hline \multirow{8}{*}{ 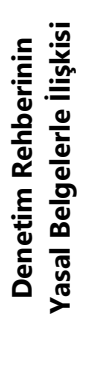 } & $\begin{array}{l}\text { 1.1. Denetim Rehberinin Yasal } \\
\text { Belgelerle Tutarlılığı }\end{array}$ & Yasal dayanağa uygunluk & 72 \\
\hline & \multirow{7}{*}{$\begin{array}{l}\text { 1.2. Denetim Rehberinin Yasal } \\
\text { Belgelerle Tutarsızlığı }\end{array}$} & Yasal dayanak belirsizliği & 15 \\
\hline & & Yasal dayanağa göre eksik ifade edilme & 10 \\
\hline & & Yasal dayanağa göre fazla ifade edilme & 9 \\
\hline & & Yasal dayanağa internet ortamında ulaşamama & 9 \\
\hline & & İlgili yasal dayanaklara eksik gönderme & 6 \\
\hline & & Yasal dayanağa göre güncel olmama & 5 \\
\hline & & Toplam & 54 \\
\hline
\end{tabular}

Tablo 2'de görüldüğü üzere denetim rehberinin yasal belgeler teması doğrultusunda tutarlılık ve tutarsızlık olmak üzere iki kategoriye ayrıldığı ve bu kategorilere ait kodların açılımına yer verilmektedir. Rehberde ilgili temaların, kategorilerin ve kodların incelenmesi neticesinde "Denetim rehberinin yasal belgelerle tutarlı̆̆ı $(n=72)$ " kategorisi altında "Yasal dayanağa uygunluk" kodu ile "Denetim rehberinin yasal belgelerle tutarsızlığ $(n=54)$ " kategorisi altında "Yasal dayanak belirsizliği ( $n=15)$ ", "Yasal dayanağa göre eksik ifade edilme $(n=10)$ ", "Yasal dayanağa göre fazla ifade edilme $(n=9)$ ", "Yasal dayanağa internet ortamında ulaşamama $(n=9)$ ", "ilgili yasal dayanaklara eksik gönderme $(n=6)$ " ve "Yasal dayanağa göre güncel olmama $(n=5)$ " tespit edilmiştir. Bu durumda "denetim rehberinin yasal belgelerle tutarlılı̆ının $(n=72)$ ", "Denetim rehberinin yasal belgelerle tutarsızlığı $(n=54)$ "' na göre daha fazla olduğu tespit edilmiştir. Bu tespit doğrultusuna rehberde çok sayıda tutarsızlık olması ile birlikte tutarlıı̆ıın daha fazla olması olumlu olarak değerlendirilebilir. Rehberde tutarlılığın nedeni rehberin hazırlandığı 2016 yılında gönderme yapılan yasal belgelerin 2020 yılana kadar hâlâ güncelliğini koruması ile açıklanabilir. Tutarsızlığının daha fazla olmasının nedeni rehberin 2016 yılında hazırlanması, çoğunlukla hazırlama safhasında okul müdürlerinin görüşlerinin alınması ve sonrasında güncellenmemesi olabilir.

\subsection{Denetim Rehberinin Yasal Belgelerle Tutarlılığı}

"Rehberinin Yasal Belgelerle Tutarlı̆ı̆ı $(n=72)$ " kategorisi altında "Yasal dayanağa uygunluk" olarak bir tane kod tespit edilmiştir. Bu kod rehberin atıfta bulunduğu maddelerin yasal dayanağına ulaşılabildiği ve yasal dayanaktaki maddelerin rehberdeki maddeler ile 
ilişkilendirildiği ve örtüştüğünü ifade etmektedir. Rehberde "Temel Eğitim, Ortaöğretim, Mesleki ve Teknik Eğitim, Din Öğretimi, Özel Eğitim ve Rehberlik ile Hayat Boyu Öğrenmeye Yönelik Ortak Alt Faaliyetler" başlığı altında yer alan "Özel Eğitim ve Rehberlik" maddeleri "1. Rehberlik ve araştırma merkezleri ile ilgili işlemler 2. Bakanlık tarafından oluşturulan özel eğitim ve rehberlik politikalarının uygulanması (...)" şeklinde ifade edilmiştir. Rehber belirtilen bu maddelerin yasal karşılığı olan "MEB ve ilç̧e Milli Eğitim Müdürlükleri Yönetmeliği Özel Eğitim ve Rehberlik Hizmetler" maddelerinin"1. Rehberlik ve araştırma merkezleri ile ilgili işlemler 2. Bakanlık tarafından oluşturulan özel eğitim ve rehberlik politikalarının uygulanması (...)" maddeleri ile bire bir örtüştüğü tespit edilmiştir (Resmî Gazete 2012,S: 28471). Bu durum rehberin yasal belgeler ile tutarlılı̆ını göstermektedir. Denetmenin yasal belgeler doğrultusunda karar alma ve uygulama süreçlerini kolaylaştıracak ve denetimde belirli bir standart sağlayacaktır. Denetleyicinin rehber ve yasal belge arasında sıkışmasına neden olmayacaktır. Denetimin rehber ve yasal belgeler arasında bir standardının olması, denetimi keyfilikten kurtaracaktır. Bu bulgu Şahin, Çek ve Zeytin (2011)'in denetmenlerin, denetimlerinde ortak kültür oluşturmalarının, kendilerinden nelerin beklendiği konusunda net olabilmelerinin, denetledikleri kurum ve kişiler açısında yararlı olacağı bulgusuyla da örtüşmektedir.

\subsection{Denetim Rehberinin Yasal Belgelerle Tutarsızlığı}

Denetim Rehberinin Yasal Belgelerle Tutarsızlı̆ı $(n=54)$ kategorisi toplam 6 koddan oluşmaktadır. Bu kodlar sırasıyla şunlardır; "Yasal dayanak belirsizliği $(n=15)$, "Yasal dayanağa göre eksik ifade edilme $(n=10)$, "Yasal dayanağa göre fazla ifade edilme $(n=9)$ ", "Yasal dayanağa internet ortamında ulaşamama $(n=9$ "), "Yasal dayanaklara eksik gönderme $(n=6)$ " ve "Yasal dayanağa göre güncel olmama $(n=5)$ " şeklindedir. Her bir kodla ilişkili bulgular rehberden doğrudan alıntılarla desteklenmiştir.

1.2.1 Yasal Dayanak Belirsizliği: "Yasal dayanak belirsizliği $(n=15)$ " kodu; denetim rehberinde ilgili konuya ilişkin yasal belgeye açıkça gönderme yapılmadığı durumlar tespit edildiğinde kullanılmıştır. Bu bağlamda rehberde "Eğitim ve Öğretim Ortamı" başlığı altında denetim standartlarından bahsederken "Birleştirilmiş sınıf uygulanan okul sayısı ve öğrenci sayısı ile genel okul ve ögrenci sayısına oranı" şeklinde ifade edilmiş. Rehberde bu ifadeye yönelik yasal belgeye ilişkin gönderme yapılmamıştır. Oysaki 18.06.2014 tarihli ve 29034 sayılı Resmi Gazete'de Yayımlanan Milli Eğitim Bakanlığına Bağlı Eğitim Kurumları Yönetici ve Öğretmenlerinin Norm Kadrolarına Illişkin Yönetmeliğin 16. maddesi 1. fıkrasındaki; "(1) ilkokullarda, ögrenci sayısı 10'dan az olmamak şartıyla açılan her şube için 1 sını öğretmeni kadrosu verilir (...)" hükümlerine göre belirlenecektir. Buna göre; Illkokullarda, öğrenci sayısı 10'dan az olmamak şartıyla sınıf oluşturulabilmektedir. 222 (Kanun No. 3579) sayılı Illköğretim ve Eğitim Kanununun 50. maddesindeki; "Birleştirilmiş sınıflar da dâhil olmak üzere bir öğretmene düşen öğrenci sayısı 40'dan dan fazla olamaz" şeklinde ifade edilmiştir (Resmi Gazete, 1961 Sayı:10705). Görüldüğü üzere rehberde yasal dayanağa ilişkin gönderme yapılmamıştır. Hâlbuki rehberde maddelerin yasal dayanağının karşılı̆ının olması denetmenin ön hazırlık, karar verme ve uygulama süreçlerine katkı sağlayacaktır. Bu durumun rehberin niteliğini olumsuz yönde etkilediği söylenebilir.

1.2.2 Yasal Dayanağa Göre Eksik ífade Edilme: "Yasal dayanağa göre eksik ifade edilme $(n=10)^{\prime \prime}$ kodu; ilgili yasal temelleri olan ancak rehberde eksik ifade edilen maddeleri temsil etmektedir. Rehberde öğretim etkinlikleri altında din öğretimi "Din kültürü ve ahlak bilgisi eğitim programlarının uygulanmasının sağlanması ve seçmeli din eğitimi derslerinin takip edilmesi, uygulanmasının gözetilmesi" şeklinde ifade edilmiştir. Rehberdeki ilgili maddenin yasal karşılığına bakıldığında Milli Eğitim Bakanlığı II ve İlçe Milli Eğitim Müdürlükleri Yönetmeliğinde, din öğretimi hizmetleri Madde 13 "(1) Din öğretimine ilişkin hizmetler a) Din kültürü ve ahlak bilgisi eğitim programlarının uygulanmasını sağlamak, b) Seçmeli din eğitimi derslerini takip etmek, 
uygulanmasını gözetmek, c) Din eğitiminde kullanılan ders kitabı ve materyallerin teminini koordine etmek." şeklinde ifade edilmiştir (Resmî Gazete, 2012 Sayl: 28471). Yönetmelikte ifade edilen "c maddesi" görüldüğü üzere rehberde ifade edilmemiştir. Bu durum yasal dayanağa göre eksik bir ifadedir. Rehberin, denetmenin el kitabı olduğu göz önüne alınarak denetlemeye gittiği II/IIçe Milli Eğitim Müdürlüğünün " c maddesinde" belirtilen denetim görevinin yerine getirilip getirilmediğinin bilinmemesi anlamına gelebilir. Bu da denetimi sorunlu hale getirir. Denetimin temel amacı, örgütün amaçlarını gerçekleştirme derecesini saptamak, daha iyi sonuçlar alabilmek için gerekli önlemleri almak ve süreci geliştirmektir (Aydın, 2014).

1.2.3 Yasal dayana göre fazla ifade edilme: "Yasal dayana göre fazla ifade edilme $(n=9)$ " kodu; ilgili madde yasal dayanakta mevcut ancak rehberde yasal dayanakta yer alan ifadeden daha kapsamlı açıklamaya yer verildiğini göstermek için kullanılmıştır. Rehberde öğretim etkinliklerinde, temel eğitimi oluşturan maddeler "1.Okul öncesi eğitimi yaygınlaştıracak ve geliştirecek çalışmalar yapılması (Milli Eğitim Bakanlığı Okul Öncesi Eğitim ve Ilköğretim Kurumları Yönetmeliği, 5490 sayılı Nüfus Hizmetleri Kanunu hükümlerince oluşturulan "Ulusal Adres Veri Tabanındaki" bilgileri kontrol edilerek e-okul sistemine kaydı yapılamayan öğrencilerin takip edilmesi) 2. ilköğretim öğrencilerinin maddi yönden desteklenmesinin koordine edilmesi 3. Okul öncesi eğitimi programlarının bir bütünlük içinde uygulanmasının sağlanması" şeklinde ifade edilmiştir. Milli Eğitim Bakanlığı II ve İlçe Milli Eğitim Müdürlükleri Yönetmeliği'nde "Temel eğitim hizmetleri" madde 10 " a) Okul öncesi eğitimi yaygınlaştıracak ve geliştirecek çalışmalar yapmak, b) ilköğretim öğrencilerinin maddi yönden desteklenmesini koordine etmek" şeklinde ifade edilmiştir (Resmî Gazete, 2012 Sayı: 28471). Rehberde görüldüğü gibi 1' inci madde yasal dayanağa göre fazla ifade edilmiştir. Rehber ve yasal belge arasındaki farklıık denetmeninin rehber ve yasal belge arasında kalmasına ve bunlardan birini tercih etmesine neden olacaktır. Bu durumun kurum denetiminde uygulama birliği ve standardı sağlamada bazı sorunlara neden olabileceği düşünülebilir.

1.2.4 Yasal dayanağa internet ortamında ulaşamama: "Yasal dayanağa internet ortamında ulaşamama $(n=9)$ " kodu; rehberin içeriğinde atıf yapılan ilgili kanun, tüzük, yönetmelik, yönerge ve genelgelere internet ortamında ulaşılamadıysa kullanılmıştır. Bu duruma ilgili belgenin çok eski olmasının ya da yürürlükten kaldııımasının etkisinin olabileceği düşünülmektedir. Rehberde "Destek hizmetleri" başlığı altında yer alan "Yemekhane iş ve işlemlerinin yürütülmesi (Besinlerle Bulaşan Hastalıklar - 2000/60, Madde Bağımlılığı-1999/29" yönetmeliklerine internet ortamında ulaşılamamıştır. Bu durumda rehberin yasal maddelerinin gözden geçirilmesi, yasalarda meydana gelen değişikliklerin internet ortamında da güncelliğinin sağlanması gerekmektedir.

1.2.5 İlgili Yasal Dayanaklara Eksik Gönderme: "ilgili yasal dayanaklara eksik gönderme $(n=6)$ " kodu; rehberde gönderme yapılan ilgili belgede başka maddelere de gönderme yapılması gerekiyorsa araştırma sürecinde gönderme yapılan yasal belgeler dışında başka destekleyici belgelere de ulaşıldıysa kullanılmıştır. Bu bağlamda rehberde yönetim faaliyetleri alt maddesinde bulunan sivil savunma ile ilgili "28.12.1988 tarih ve 20033 sayll R.G.de yayımlanan Sabotajlara Karşı Koruma Yönetmeliği"ne atıfta bulunulmuştur. Ancak "Sivil Savunma Biriminin Görevleri (16/02/2015 tarihli 48680469/10.06/1723363 sayılı MEB 2015/3) Genelgesi"'ne atıfta bulunulmamıştır. Sivil savunma planlarını hazırlamak ve bu planları güncellemek, kurumun tahliyeye ilişkin planlamasını koordine etmek ve sivil savunma servislerinin kuruluşunu sağlamak ve eğitimlerini yaptırmak açısından önemli bir genelgedir. Bu genelgeye ilave olarak deprem ve yangın gibi doğal afetlerle mücadeleye dönük faaliyetler ve alınan tedbirler kapsamında "18/12/2013 tarihli ve 28855 sayll "Afet ve Acil Durum Müdahale Hizmetleri" yönetmeliğine rehberde gönderme yapılması gerektiği düşünülmektedir. Bu bağlamda rehber hazırlanırken yasal belgeler ve bu belgeleri destekleyici diğer belgeler üzerinde daha detaylı incelemeler yapılabilir. 
1.2.6 Yasal Dayanağa Göre Güncel Olmama: "Yasal dayana göre güncel olmama $(n=5)$ " kodu; rehberdeki ilgili maddenin mevzuattaki karşılığı değişmişse, rehberde güncellenmediyse veya ilgili madde mevzuatta yürürlükten kaldırılmışsa ama rehberde hâlâ yer alıyorsa tercih edilmiştir. Rehberde "Rehberlik ve Denetim Sürecinin Planlanması ve Yürütülmesi" alt maddesi altında bulunan ön çalışma maddelerinde maarif müfettişlerin gerçekleştireceği rehberlik ve denetim öncesinde kurumla ilgili (okul, okul müdürü, müdür yardımcıları, öğretmenler) ihtiyaç duyabileceği bilgileri toplayarak bir ön araştırma yapmaları ifade edilmiştir. 24 Mayıs 2014 tarihinde Resmî Gazete'de yayımlanan 29009 sayılı, "Millî Eğitim Bakanlığı Rehberlik ve Denetim Başkanlığı ile Maarif Müfettişleri Başkanlıkları Yönetmeliği'"nden sonra ders denetimi faaliyetleri maarif müfettişlerinin görev ve yetkisinden alınarak okul müdürlerine devredildiği tespit edilmiştir. Bu durumda rehberlik ve denetim rehberlerinin değişen mevzuatlar karşısında geride kalmaması için belirli aralıklarla güncellenmesi ve yasal dayanaklar çerçevesinde revize edilmesi gerekmektedir. Bu tespit, Altınışık ve Binbir'in (2015) de ulaştığı 2000-2014 yılları arasında Türk eğitim sisteminde mevzuatların sıklıkla değiştirildiği bulgusunu desteklemektedir. Bu bağlamda rehberin 2016 yılında yayınlandığı göz önüne alınırsa 2020 yılına kadar değişen mevzuatlar karşısında güncellenmediği söylenebilir.

\section{2. İ/illçe Milli Eğitim Müdürlükleri Rehberlik ve Denetim Rehberinin Alanyazın Temelli İncelenmesi}

il/ilçe Milli Eğitim Müdürlükleri Rehberlik ve Denetim Rehberi'nin alanyazınla ilişkisi teması altında "Denetim rehberinin alan yazınla tutarlıı̆ı" ve "Denetim rehberinin alanyazınla tutarsızlığı" olmak üzere iki kategori ortaya çıkmaktadır. Bu kategoriler kendi içinde kodlardan oluşmaktadır. Bu kodlar doğrultusunda elde edilen bulgular Tablo 3'te verilmiştir. Bu kısımda denetim rehberi ile ilgili doğrudan bir alanyazın çalışması olmadığından çalışmalar temelinde hareket edilmiş olup sayısallaştırmaya gidilmemiştir.

Tablo 3:

"Denetim Rehberinin Alanyazınla ilişskisi " teması altında ortaya çıkan kategori kodların dağılımı

\begin{tabular}{|c|c|c|}
\hline TEMA & KATEGORILER & KODLAR \\
\hline \multirow{2}{*}{ 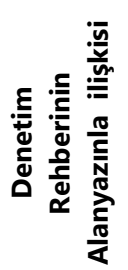 } & $\begin{array}{l}\text { 2.1 Denetim Rehberinin } \\
\text { Alanyazınla Tutarılığı }\end{array}$ & Uygunluk \\
\hline & $\begin{array}{l}\text { 2.2. Denetim Rehberinin } \\
\text { Alanyazınla Tutarsızlığı }\end{array}$ & $\begin{array}{l}\text { Atıfsızlık } \\
\text { İçerik eksikliği } \\
\text { Kavram Tutarsızlığı } \\
\text { Aykırılık }\end{array}$ \\
\hline
\end{tabular}

Tablo 3'te denetim rehberinin alanyazınla ilişkisi teması kapsamında kategori ve kodlara ait sonuçları yer almaktadır. "Denetim rehberinin alanyazınla ilişkisi" teması altında "Denetim Rehberinin Alanyazınla Tutarlıı̆ı" ve "Denetim Rehberinin Alanyazınla Tutarsızlığı" olmak üzere iki kategori mevcuttur. "Denetim Rehberinin Alanyazınla Tutarlıı̆ı" kategorisi kapsamında "Uygunluk" kodu, "Denetim rehberinin alanyazınla tutarsılığı" kategorisi kapsamında "Atıfsızlı", "içerik eksikliği", "Kavram Tutarsızlı̆̆ı" ve "Aykırılık" olmak üzere dört kod tespit edilmiştir. Denetim rehberi alanyazın temelinde incelendiğinde genel olarak tutarlılı̆ının tutarsızlığına göre daha fazla olduğu tespit edilmiştir. Bu tespit bağlamında rehberin alanyazın ile tutarlılı̆ın fazla olması bilimsel açıdan olumlu olarak değerlendirilebilir.

\subsection{Denetim Rehberinin Alan Yazınla Tutarlıığı}

"il/ilçe Milli Eğitim Müdürlükleri Rehberlik ve Denetim Rehberi'nin" alanyazınla ilişkisi incelendiğinde rehberin alan yazın ile genel olarak tutarlı olduğu tespit edilmiştir. Bu bağlamda rehberde "Bulguların Elde Edilmesi ve Önerilerin Geliştirilmesi" başlığı altında "Denetim grubu bu 
aşamada, kendi içinde yaptığı görev paylaşımı doğrultusunda, denetim sürecinde bulgulara ulaşma yoluna gider. Denetim sonucunda elde ettiği bulguları değerlendirerek, kurum yönetimi ve çalışanlarına katkı sağlayarak, kurumun performansını artıracak öneriler geliştirir." şeklinde ifade edilmiştir. Ifadede "kurumun performansını artıracak öneriler geliştirir." ibaresi, çağdaş denetimde önem kazanan kavramlardan biridir. Türkiye'de özellikle 2004-2005 eğitim öğretim yılından sonra performans değerlendirmeye yönelik katılımcı bir denetim anlayışı benimsenmiştir. Aydın'a (2014) göre performans değerlendirme ve geliştirme, iş görenin örgüt içindeki etkinliklerinin yönetici tarafından analizinin yapılması ve kişiden istenenin ne ölçüde gerçekleştirdiğidir. Alan yazındaki bu ifadenin rehberdeki kurumun performansını artıracak önerilerle tutarlı olduğu tespit edilmiştir.

\subsection{Denetim Rehberinin Alanyazınla Tutarsızlığı}

"Denetim Rehberinin Alan Yazın ile Tutarszzlı̆ı" kategorisi toplam dört koddan oluşmaktadır. Bunlar; "alanyazına atıf, içerik eksikliği, kavram tutarsızlığı" ve "aykırılık" kodlarıdır. Her bir kodla ilişkili bulgular rehberden doğrudan alıntılarla desteklenmiştir.

2.2.1. Atıfsızlık: "Atıfsızlık" kodu rehberin alanyazınla ilişkisi ister tutarlı ister tutarsız olsun rehberin konusu ile ilgili yapılmış bilimsel çalışmalara gönderme yapılmaması durumunu ifade etmektedir. Bütünü incelendiğinde rehberin hiçbir yerinde alanyazındaki herhangi bir araştırmaya, kitaba, makaleye, çalışmaya atıfta bulunulmadığı görülmektedir. Alanyazın incelendiğinde ise rehberin kapsamında olan denetim ilkeleri ile ilgili atıfta bulunulan araştırmaların (Gökçe, 1994; Başar, 2000) olduğu tespit edilmiştir. Bu bulgunun elde edilmesinin sebebi rehberin daha çok mevzuat odaklı hazırlanarak bilimsel bilginin göz ardı edilmesi şeklinde açıklanabilir. Bu bağlamda rehberin alanyazın ile bir bütünlük içinde olması rehberin daha bilimsel olmasına katkı sağlayacaktır. "Eğitim denetiminin bilimsel olabilmesi için kararların ve eylemlerin bilgiye dayandırılması gerektiğini ifade eden" Hoy ve Miskel (1978) denetimde bilginin önemini açıkça belirtmektedir. Etkili bir denetimsel davranışın kavramlara, tanımlara ve varsayımlara yani kuramlara dayandığı bilinen bir olgudur. Kuram, yöneticilerin ve denetmenlerin gerçeğe ulaşmada kullandıkları en önemli güvenilir araçlardan birisidir (Bursalıoğlu, 1979:20). Zaten eğitbilimciler eğitim pratiğinin teorilerini hazırladıklarında, bu teoriler üretildiği toplumun ve belki de uluslararası toplumun gerçekten yasal belgelerine yansıdığında ancak eğitim bilimliğinden söz edilebilir (Toprakçı, 2008; Toprakçı, Dağdeviren, Oflaz ve Türe 2010). Eğitim denetiminin nitelik ve nicelik olarak bilimsel bir zemine oturtturulması isteniyorsa akademisyenlerin çalışmalarından yararlanmaları hem denetimde uygulamaya yönelik araştırmalarda, hem de akademisyeni takdir etmek bağlamlı katkı sağlayıcı olabilir.

2.2.2. İçerik eksikliği: "içerik eksikliği" kodu alanyazında mevcut olan ancak rehberde eksik olan durumlar tespit edildiğinde kullanılmıştır. Rehberde "Rehberlik ve denetimde ilkeleri" başlığı altındaki maddeler "Bireysel ve kurumsal farklılılar ile çevresel faktörleri dikkate almak, yol gösterici ve önleyici rehberliği öne çıkarmak, düzeltmeyi, iyileştirmeyi ve geliştirmeyi esas almak, iyi uygulama örneklerini yaygınlaştırmak, usulsüzlük ve yolsuzlukları önleme yönelimli olmak, açıklık, şeffaflık, eşitlik, demokratiklik, bağımsızlık, bütünlük, güvenilirlik ve tarafsızlığı esas almak (...)" şeklinde ifade edilmiştir. Ancak alanyazın incelendiğinde, Göker ve Gündüz 'e (2017) göre denetim hizmetlerinin yürütülmesi ve yönetilmesinde önemli bir yer tutan denetim raporlarının ve geribildirimlerin paydaşlar arasında paylaşılmasının hesap verebilirliği eğitim sistemlerinde ön plana çıkmasıyla olacağını ifade etmişlerdir. Ancak rehberde "rehberlik ve denetim ilkeleri" arasında hesap verilebilirlik ilkesi mevcut değildir. Burada alanyazında olup rehberde olmayan eksik bir ifade vardır. Rehberde hesap verilebilirliğin ve şeffaflı̆ın eğitim ve denetim sürecine yansımalarını belirlemek ve ilkelerini ortaya koymak, denetsel raporlar ile birlikte denetsel eylemler sonucunda verilen geribildirimlerin eğitim sistemine önemli katkı sağlayacağı düşünülmektedir. 
2.2.3. Kavram Tutarsızlığı: "Kavram tutarsızığı" kodu alınyazındaki kavramlar ile rehberdeki kavramların kullanımı tutarsız olduğunda ya da birbirini kapsayan kavramlar tespit edildiğinde kullanılmıştır. Nitekim rehberde denetimin tanımı "Genel olarak kamuda, özel ve tüzel kişiliği bulunan kurum ve kuruluşlarda yapılmakta olan işlerin; kaynak, imkan ve şartlar dikkate alınarak, yasal çerçeve ile belirlenen amaç, öngörülen temel ilke ve hedeflere uygunluğunu, doğruluğunu, düzenliliğini, verimliliğini, ekonomikliğini, etkinliğini; objektif, geçerli, güvenilir ölçütlere göre karşılaştırma yapabilme, ulusal standartlara ve planlanan esaslara göre durumunu ortaya koyma, giderilebilir eksiklikler için rehberlikte bulunma, değişim ve gelişim için misyon ve vizyon kazandırmaya ilişkin öneriler getirme sürecidir." şeklinde ifade edilmiştir. Tanımdan da anlaşılacağı üzere denetimde hedeflenen önemli amaçlardan birkaçı ise rehberlikte bulunma, değişim ve gelişim için öneriler sunma sürecidir. Denetimin temel amacı, örgütün amaçlarını gerçekleştirme derecesini saptamak, önlemler almak, süreci izleme, inceleme, değerlendirme ve geliştirmektir (Aydın, 2014:1).

Bu bağlamda rehberde ilgili birçok maddede denetim ve rehberlik kavramlarının birlikte kullanıldığı tespit edilmiştir. Tanımdan da anlaşılacağı üzere denetim tanımsal ve kavramsal olarak rehberliği de içine almaktadır. Bu nedenle rehberde anahtar kelimelerin tanımlamaları yapılırken alanyazında gerekli olan yerler temel alınabilir.

2.2.4. Aykırılık: "Aykırılık" kodu denetim rehberinde alanyazınla çelişkili bölümlere yönelik durumlar tespit edildiğinde kullanılmıştır. Bu kodu oluşturan bulguyla ilgili olarak rehberde "Rehberlik ve denetim ilkeleri" başlığı altında yer alan "i) Millî birlik ve bütünlügümüzün temel unsurlarından biri olan Türkçenin doğru kullanılması hususunda gerekli duyarlı̆ğı göstermek" maddesi örnek olarak verilebilir. Bu örnek bağlamında alanyazın incelendiğinde; rehberde ifade edilen maddenin alanyazında "denetim ilkeleri" arasında yer almadığı tespit edilmiştir. Bu bulgunun Taymaz'ın (2015) "müfettişlerin rehberlik, denetim ve yardım sürecinde bulunması ve uyulması gereken ilkeler" başığı altındaki maddeler ile de uyuşmadığı tespit edilmiştir. Bundan dolayı bu maddenin rehberde denetim ilkesi olarak değil, metin içerisinde farklı bir yerde ifade edilmesinin uygun olacağı değerlendirilmiştir.

\section{SONUÇ VE ÖNERILER}

Bu çalışmada Milli Eğitim Bakanlığının yayımladığı 2016 tarihli "il/ilçe Milli Eğitim Müdürlükleri Rehberlik ve Denetim Rehberi" yasal belgeler ve alanyazın temelinde içerik olarak incelenmiştir.

Yasal belgelerle ilişkisinin incelenmesi sonucunda rehberin bazı yasal maddelerinin güncel olmadığı ya da yürürlükten kalktığı ve mevzuatların çok sıklıkla değiştiği anlaşılmıştır. Rehberde bazı ifadelerin yasalarda karşılığı olmakla beraber çoğu ifadenin yasal karşılığı mevcut değildir. Rehbere ait ilgili maddelerin yasal dayanaklarının hızlı değişmesi özellikle denetmenlerin ve eğitim paydaşlarının değişen yasalar karşısında geride kalmasına ve kendilerini yenileyememesine neden olmaktadır. Rehber bütünsel olarak hazırlanırken sadece MEB'e bağlı kurumların görüşü alınarak yasal düzenlemelere gidilmesi yanıltıcı ve hatalı olabilir. Nitekim rehberin yasal belgelerle ilişkisinin incelenmesi neticesinde; bazı maddelerde yasal dayanağa göre eksik ifadelerin olduğu, bazı maddelerde ilgili yasal belgeye göre dayanak verilmeksizin fazla ifadelerin yer aldığı veya yasal belgenin hatalı ifade edildiği gibi bulgulara ulaşılmıştır.

Bu bağlamda;

- Rehberin değişen yasal belgelere bağlı olarak daima güncel tutulması gerektiği söylenebilir.

- Güncel tutmak adına rehberle ilgili maarif müfettişlerinden oluşan bir çalışma kurulu oluşturulabilir.

- Rehber hazırlanırken MEB'in üst kurullarında alınan görüş ve kararlara ilave olarak tüm eğitim paydaşlarının (akademisyen, sivil toplum örgütleri, okul müdürleri, 
müdür yardımcıları, öğretmenler vb.) görüşlerinin alınması rehberin hem nicelik hem de nitelik yönünden daha yeterli olmasını sağlayacaktır.

- Teftiş Kurulu Başkanlığının resmi web sayfasında yayımlanan, rehberlik ve denetim kılavuzlarının erişime açık olan ilyilçe Milli Eğitim Müdürlükleri Rehberlik ve Denetim Rehberi'nin ilgili maddelerinin karşısına yasal dayanağını gösteren link bağlantılarının internet ortamında kurulması sağlanabilir. Bu link sayesinde yasal belgeler anında ulaşılabilir hâle getirilmiş olur.

- Milli Eğitim Bakanlığınca uygulanan hizmet içi ve dışı eğitimlerde eğitim paydaşlarına rehberin kullanımı, öğretimsel denetimde uygulanması, mevzuat değişiklikleri ve güncellemeler ile ilgili bilgilendirme yapılarak hem teoride hem de pratikte yetkinlikler kazandırıması sağlanabilir.

- Müfettişlerin, müdürlerin ve öğretmenlerin ağırlıkı olarak lisansüstü eğitim yaptıkları Eğitim Yönetimi Teftişi, Planlaması ve Ekonomisi lisansüstü eğitim programlarında denetim derslerinin uygulama bazlı yürütülmesi için maarif müfettişlerinin katıımı sağlanarak yaşanmış örnek hikâyelerle alana ve uygulayıcılara pratiklik kazandırılabilir.

- Müfettişlik bir kariyer mesleği olarak kabul edilmeli ve özendirilmelidir. Teftiş hizmetleri sınıfı oluşturulmalı, bu konuda gerekli yasal düzenlemeler yapılmalıdır.

- Rehberle ilgili yasal maddelere internet ortamında çeşitli mevzuatlar veya Resmî Gazete ve yönergeler kapsamında ulaşılmaktadır. Bu durum gerek denetmenler için gerekse araştırmacılar için çok zaman almakta, enerji ve maliyet yönünden kayıplara yol açmaktadır. Bu kayıpların minimize edilmesi için rehbere ait ilgili kanun, tüzük, yönetmelik ve genelgeler bir araya getirilerek dijital ortamda tek bir internet adresinde toplanmasında ve müfettişlere ulaştırılması konusunda kolaylık sağlanması önerilebilir.

Rehberin alanyazın temelinde incelenmesi neticesinde; genel olarak tutarlıı̆ının tutarsızlığına göre daha fazla olduğu tespit edilmiştir. Bu tespite göre rehberin alanyazın ile tutarlılığın fazla olması bilimsel açıdan olumlu olarak değerlendirilebilir. Ancak rehberin hiçbir yerinde alanyazındaki herhangi bir araştırmaya, kitaba, makaleye, çalışmaya atıf olmadığı tespit edilmiştir. Rehberlerin daha bilimsel olabilmesi adına atıf eksikliğinin alanyazına gitmeme durumunun bir sorun olduğu ve rehberin bilimselliğini olumsuz etkilediği söylenebilir. Bu bağlamda alanyazından istifade edilmeye çalışılması sağlanabilir. Ayrıca rehberin metin olarak denetim sürecinde bilimsel ölçütlerin karşılanması konusunda eksikliklerin olduğu da söylenebilir. Bu eksikliklerin nedeni;

- Teftiş hizmetlerini yerine getiren müfettişlerin denetimin bilimsel temelleri ve bilimsel veri toplama konusunda yetkinliklerinin sınırlı olması, bu alanda gerekli olan lisansüstü eğitimi almamış olmaları ile ilgili olabilir.

- Rehberde denetim sürecinde izlenmesi gereken adımlarda ve inceleme yaparken kullanılacak araçlarda içerik eksikliği, kanıtlayıcılık ve ölçülebilirlik konularında bazı eksiklikler olduğu tespit edilmiştir.

Bu tespit bağlamında;

- Teftiş sonuçlarının ve personelin daha efektif olabilmesi, dünyanın hızla değişen ve yenileşen şartları içinde bilimsel yöntem ve araçların geliştirilmesi, yurtiçi ve yurtdışı alanyazından yararlanılması önerilebilir.

- Denetmenlerin daha bilimsel yöntemler kullanabilmeleri için değişen dünyayı takip etmeleri, hem ulusal hem de uluslararası inceleme ve araştırma yapmaları, alanları ile ilgili yerli ve yabancı basını, yenilikleri izleyebilmeleri, yurt dışına çıkmaları ve meslekte gelişmeleri sağlanmalıdır.

- Denetmenlerin MEB'e bağlı okul, kurum, birim ve personeli objektif olarak değerlendirebilmesi için bilimsel yöntem, teknikler, ölçütler ve araçlar 
kullanılmalıdır. Bu bilimsel yöntem, teknikler, ölçütler ve araçların kullanılması için denetmenlere hizmet içi ve dışı eğitimler sağlanabilir.

- MEB tarafından denetimde, denetim sürecinde izlenmesi gereken adımları ve inceleme yaparken kullanılacak araçları açıklayan cep kılavuzları hazırlanmalı, ayrıca denetimle ilgili bilimsel çalışmaları ve gelişmeleri izleyebilen, yayabilen bir yayın olmalıdır.

- Araştırmacılar için denetim rehberinin alanyazın ile ilgili daha detaylı bir araştırmaya tabii tutulması önerilebilir.

- Rehberin alanyazın temelinde hazırlanması ve kontrolünün sağlanması amacıyla akademisyenlerden oluşan bir bilimsel kurul oluşturulabilir

- Rehberde alanyazınla ilgili olarak içerik eksikliği ve kavram tutarsızlığı olan ifadeler tespit edilmiştir.

Denetmenlerin mesleki, alan ve genel kültür bilgisi yanında, alanyazına da hâkim olmaları gerekmektedir. Bu nedenle denetmenlerin lisansüstü eğitim almaları için teşvik edilmesi önerilebilir. Bu konuda gerekli teşvik ve yasal düzenlemeler yapılabilir. Ayrıca denetim rehberini kullanan deneticilerin rehberin işlevselliğine yönelik görüş ve önerileri alınarak araştırma genişletilebilir. II/ilçe milli eğitim müdürleri ile rehber bağlamında yapılan denetime ilişkin görüşmeler yapılarak rehberin geliştirilmesi bir başka araştırmanın konusu olabilir.

\section{KAYNAKÇA}

Akbaba-Altun, S. (2000). Okul müdürlerinin bilgi teknolojilerine ilişkin görüşleri. Kuram ve Uygulamada Eğitim Yönetimi, 37, 46-71.

Akın, U. (2016), Türk Eğitim Sistemi ve Okul Yönetimi. Ankara: Pegem Akademi

Aydın, M. (2008). Çağdaş eğitim denetimi. Ankara: Hatipoğlu Yayınevi,

Aydın, M. (2014). Çağdaş eğitim denetimi (6. Baskı). Ankara: Gazi Kitabevi.

Aypay, A. (2010). Denetici Profiline illişkin Sorunlar. Türk Eğitim Bilimleri Dergisi, $8(3), 593-622$.

Ayral, M. (2007). Okulda bilgi yönetimi model önerisi kapsamında yönetici ve öğretmen görüşlerine göre Ankara ili okullarının değerlendirilmesi (Doktora tezi). Ankara Üniversitesi, Eğitim Bilimleri Enstitüsü, Ankara.

Altınışık, S ve Binbir, Ü. (2015). Eğitim ve Toplum Yazıları. M. B. Aksu ve H. Şimşek (Ed.) içinde, Son Onbeş Yılda Türkiye'de Eğitim Denetimine illişkin Yapılan Tezlerin Analizi (ss. 83-104). Ankara: Gazi Kitapevi.

Altunay, E. (2016)."Eğitim Denetimi" Eğitbilim-Pedandragoji içinde (Editör:Erdal Toprakçı). Ankara: Ütopya Yayıncilık.

Başar, H. (2000). Eğitimde çağdaş denetim yaklaşımları. Eğitim denetçisi. Ankara: Pegem Yayıncılık.

Başaran, İ. E. (2006). Türk eğitim sistemi ve okul yönetimi, Ekinoks Yayınları, Ankara.

Beytekin,F.O. ve Tas, S. (2017), Ortaokul Müdürlerinin Öğretimsel Denetimine Görüşlerinin incelenmesi. International Periodical for the Languages, Literature and History of Turkish or Turkic Volume 12/33, p. $115-128$

Bursalığlu, Z. (1979). O Okul Yönetiminde Yeni Yapı ve Davranış. Ankara Üniversitesi Eğitim Fakültesi Yayınları No:78.

Büyüköztürk, Ş. (2018). Bilimsel Araştırma Yöntemleri. Ankara: Pegem Akademi.

Can, Niyazi (2018). Eğitim Yönetimi. Ankara: Pegem Akademi.

Çelebi, N., Övür, M. \&Eravcı, F. (2016). Soruşturma Grubunda Görev Yapan il Eğitim Denetmenlerin Süreç içinde Karşılaştıkları Sorunlar. MCBÜ Sosyal Bilimler Dergisi, Cilt 15, Sayı: 1.

De Grauwe, A.(2008). Directions in educational planning: Symposium to honour the work of Francaise Caillods: School supervision: a tool for standardization or for equity?,International Institute for Educational Planning, Working Document.3-4 July

Demirkasımoğlu, N. (2011). Türk Eğitim Sisteminde Bir Alt Sistem Olan Denetim Sisteminin Seçilmiş Bazı Ülkelerin Denetim Sistemleri ile Karşılaştırılması, Abant İzzet Baysal Üniversitesi Sosyal Bilimler Enstitüsü Dergisi, Cilt 2, Sayı 23.

Durnalı, M., \& Limon, İ. (2018). Çağdaş Türk eğitim denetimi sistemi (değişimler ve yasal dayanakları). Kastamonu Education Journal, 26(2), 413-425.oi:10.24106/kefdergi.38980 
Feyereisen, Kontryn V., A. John Fiorino-Arlene T. Nowak, (1970) Supervision and CuuriculumRenewal: A System Approach, Appleton- Century-Crofts,New York

Gökçe, F. (1994). Eğitimde Denetimin Amaç ve Ilkeleri. Hacettepe Üniversitesi Eğitim Fakültesi Dergisi, 10, 73-78.

Göker, D.S. ve Gündüz, Y. (2017). Eğitim Denetimi Sürecinde Hesap Verilebilirlik ve Şeffaflık Uygulamaları. Ondokuz Mayıs Üniversitesi Eğitim Fakültesi Dergisi, Volume 36, Issue 1, Pages 83-93.

Gönülaçar, Ş. (2018). Eğitim Denetiminde Dönüşüm Sancısı. Eğitime Bakış, Sayı 43, s. 88 - 97.

Gündüz, Y. ve Can, E. (2013). Türkiye'de eğitim denetimi uygulamalarında karşılaşılan temel sorunlar. V. Uluslararası Katılımlı Eğitim Denetimi Kongresi Bildiri Kitabı (ss.717723).

Gündüz,M (2016). Maariften Eğitime Tanzimat'tan Cumhuriyet'e Eğitim Düşüncesinde Dönüşüm, Doğu Batı Yayınları, Ankara, 2016, s. 61, 334

Hoy, Waynek, Cecil G.Miskel, Educational Administration, Theory, Research, and Practice, Random house, New York, 1978.

Katz, Robert L. "Skills of an Effective Administrator", Harvard Business Review, Vol.33, No. 1a,1955

Kılıç, A.,Aslanargun, E. Ve Kılıç Abdurrahman (2013). Eğitim Denetmenlerinin Rehberlik, Denetim, Inceleme ve soruşturma görevlerine yönelik bir olgu bilim araştırması. Milli Eğiti. Sayı 197

Kondakçı Y., S. Emil ve K. Beycioğlu (Ed.) 14. Uluslararası Eğitim Yönetimi Kongresi içinde (s. 829-834). Ankara: Orta Doğu Teknik Üniversitesi.

MEB (2015). Teşkilat Şeması. [Çevrim-içi: http//www.meb.gov.tr/meb/meb_teskilat_s emasi2015.png].

MEB (2016a). Rehberlik ve Denetim Başkanlığı-Birimlerimiz. [Çevrim-içi: http://rdb.meb. gov.tr/www/birimlerimiz /kategori/3].

MEB (2016b). Rehberlik ve Denetim Başkanlığı-Yayınlarımız. [Çevrim-içi: http://rdb.meb. gov.tr/www/yayinlarimiz/icerik/13].

MEB (2017). Teftiş Kurulu Yönetmeliği, https://www.mevzuat.gov.tr/mevzuat?MevzuatNo=23861\&MevzuatTur=7\&MevzuatTertip=5, Erişim tarihi 15.05 .2020

MEB (2019). Bakanlık Maarif Müfettişleri Görev Standartları, https://tkb.meb.gov.tr/meb_iys_dosyalar/2019_06/19145017_Bakanlık_Maarif_Müfettiş-leri_Görev _Standartları.pdf, Erişim tarihi 04.06.2020

MEB İl ve İlçe MEM Yönetmeliği.(2012) http://mevzuat.meb.gov.tr/dosyalar/1616.pdf Erişim tarihi 04.06.2020

MEB IIl ve İlçe MEM Yönetmeliği. Özel Eğitim ve Rehberlik Hizmetleri (Resmi Gazete, 2012, Sayı:28471) https://www.mevzuat.gov.tr/mevzuat?MevzuatNo=16774\&MevzuatTur=7\&MevzuatTertip=5. Erişim tarihi. 18.05.2020

Milli Eğitim Bakanlığı [MEB] (2018). Özel Eğitim Hizmetleri Yönetmeliği, https://www.mevzuat.gov.tr/mevzuat?MevzuatNo=24736\&MevzuatTur=7\&MevzuatTertip=5, Erişim tarihi 15.05 .2020

MEB Rehberlik ve denetim başkanlığı maarif müfettişleri görev standartları. ( 2015)

MEB İ/ilç̧e Eğitim Müdürlükleri Rehberlik ve Denetim Rehberi. (2016)

Memişoğlu ve Sağır (2008). Illköğretim kurumlarında görevli öğretmenlerin işbaşında yetişmelerinde müfettişlerin denetim rolüne ilişkin yönetici algıları. Abant İzzet Baysal Eğitim Fakültesi Dergisi cilt:8, sayı:2

Miles, J. A. (2016). Yönetim ve organizasyon kuramları. (Çev. Mustafa Polat-Korhan Arun). Ankara: Nobel Yayıncılık.

Özkan, H.ve Çelikten, Y. (2017). Milli Eğtim Sisteminin Örgütsel Yapısı ve Maarif Müfettişleri Alt Sistemleri işleyişi. Uluslararası Toplum Araştırma Merkezi. DOI: 10.26466/opus.321994

Resmi Gazete (1973). Milli Eğitim Temel Kanunu.(Kanun No:1739) https://www.resmigazete.gov.tr/arsiv/14574.pdf. Erişim tarihi15.05.2020

Resmi Gazete (2011). Millı̂ Eğitim Bakanlığının Teşkilat ve Görevleri Hakkında Kanun Hükmünde Kararname (Karar Sayısı: KHK/652).

Resmi Gazete (1961). Illköğretim ve Eğitim Kanunu.(Kanun no:222)

Sağlam, Ç. ve Aydoğmuş, M. (2016). Gelişmiş ve gelişmekte olan ülkelerin eğitim sistemlerinin denetim yapıları karşılaştırıldığında Türkiye eğitim sisteminin denetimi ne durumdadır? Uşak Üniversitesi Sosyal Bilimler Dergisi 9/1.

Sarpkaya, R. (2004). İlköğretim denetmenlerinin denetim sürecinde karşılaştıkları sorunlar. https://www.researchgate.net/publication/324648517. Erişim tarihi (24.6.2010) 
Süngü, H. (2002). Bazı Avrupa Birliği ülkeleri eğitim denetimi sistemlerinin Türkiye'deki okul yöneticileri tarafından değerlendirilmesi (Kırıkkale ili örneği). Yayınlanmamış Yüksek Lisans Tezi. Kırıkkale Üniversitesi Sosyal Bilimler Enstitüsü, Kırıkkale.

Süngü, H. (2005). Fransa, Ingiltere ve Almanya egitim denetimi sistemlerinin yapısı ve isleyisi. Milli Egitim Dergisi.167. (http://yayim.meb.gov.tr/dergiler/167/index3-sungu.htm). Erisim: 12.02.2014

Şahin, S., Çek, F., Zeytin, N. (2011). Eğitim Müfettişlerinin Mesleki Memnuniyet ve Memnuniyetsizlikleri. Kuram ve Uygulamada Eğitim Yönetimi, Cilt 17, Sayı 2, ss: 221-246

Şahin, İ. (2017) Öğretmen ve Müfettiş Penceresinden Rehberlik ve Denetim Çalışmalarına Bakış Kuramsal. Eğitimbilim Dergisi - Journal of Theoretical Educational Science, 10(2), 251-273

Taymaz, H. (2015).Eğitim sisteminde teftiş: Kavramlar, ilkeler, yöntemler. Ankara: Pegem Yayıncılık.

Tezcan, M. (2015). Eğitim Sosyolojisi (Genişletilmiş 15. Baskı). Ankara: Anı Yayıncılık.

Toprakçı, E.(2008). Sınıfa Dayalı Yönetim. Ankara: Pegem Yayınları.

Toprakçı, E. \& Kadı, A. (2014). Türkiye'deki bakanlıkların eğitim yönetimi ve denetimi alanındaki faaliyetlerinin yasal belgeler eşliğinde analizi. Celal Bayar Üniversitesi Sosyal Bilimler Dergisi, 12(4), 118.

Toprakçı, E. \& Akçay, A. (2016). Türkiye'de kamu yararına çalışan derneklerin eğitim faaliyetlerinin yönetimi ve denetimi (Yasal belgeleri temelinde nitel bir analiz). Cumhuriyet International Journal of Education-CIJE, 5(1), 29-52.

Toprakçı, E. ve Bakır, D. (2019). 2012-2017 yılları arası Milli Eğitim Bakanlığı Sayıştay denetim raporlarının incelenmesi.

Toprakçı, E., Dağdeviren, İ., Oflaz, G., ve Türe, E.(2010) Eğitim Fakültesi Öğretim Elemanlarının Bilim Anlayışları Temelinde Eğitimin Bilimliliği" Bilim ve Ütopya Dergisi Sayı:190, Yıl:10, Nisan 2010 ss4556.

Tonbul, Y. \& Baysülen, E. (2017). Ders Denetimi ile Illgili Yönetmelik Değişikliğinin Maarif Müfettişlerinin, Okul Yöneticilerinin ve Öğretmenlerin Görüşleri Açısından Değerlendirilmesi. http://dergipark.ulakbim.gov.tr/ilkonline/article/view/5000186323 Erişim: 5 Ağustos 2018

Yıldırım, A.; Şimşek, H. (2013). Sosyal bilimlerde nitel araştırma yöntemleri. Ankara: Seçkin Yayıncılık. Yıldırım,A.:Şimşek, H. (2016). Sosyal Bilimlerde Nitel Araştırma Yöntemleri. Ankara: Akademik ve Mesleki Yayıncılık. 


\section{The examination of Provincial/District National Education Directorates Guidance and the Supervisory Guide Based on Legal Documents and Literature}

\author{
Dr. Özden Ölmez Ceylan \\ Ministiry of National Education-Turkey \\ olmezozden@gmail.com
}

\author{
Erhan Algam (M.A.Stud.) \\ Özel Kocatürk Primary School-Turkey \\ erhanalg@yahoo.com
}

\begin{abstract}
The purpose of this research is to examine the "Provincial / District National Education Directorates Guidance and the Supervisory Guide" on the basis of legal documents and literature, in order to develop suggestion according to findings. In accordance with the research problem, document review technique was used on the basis of qualitative research. In this context, the study document of the research consists of published articles, masters/doctoral theses and legal regulations. The collected data was analyzed by content analysis. According to the results of the research, the guideline was generally consistent on the basis of legal documents, however, some of them were out of date or abolished. As a result of examining literature, the guideline was generally consistent with the literature, but none of the statements was referred to in the literature. Some of the suggestions are made based on these findings that the legal documents which are in the guideline should be collected in an internet address in a digital environment, and a unit or expert in the central organization should be assigned in order to deliver it to supervisors. A study board consisting of supervisors related to guide should be established in order to keep it up to date, A science board consisting of academicians is established in order to prepare the guide on the basis of the literature and to ensure its control.
\end{abstract}

Keywords: Supervisory guideline, povincial/district national education directorates.

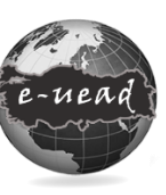

E-International Journal of Educational Research, Vol:11, No: 3, 2020, pp.179-198

DOI: $x x x x x x x$

Received: $x x . x x . x x x x$ Revision (if there is): $x x . x x . x x x x$ Accepted: $x x . x x . x x x x$

\section{Suggested Citation:}

Ölmez Ceylan, Ö. \&. Algam, E. (2020). The Examination of Provincial/District National Education Directorates Guidance and the Supervisory Guide Based on Legal Documents and Literature, E-International Journal of Educational Research, Vol: 11, No: 3, 2020, pp. 179-198, DOI: xxxxxxxxxxxx 


\section{EXTENDED ABSTRACT}

Problem: One of the main factors affecting the level of development of societies is the quality of education. In order to boost the quality of education, it is necessary to ensure that the components of the system work efficiently. At this point, it requires an efficient supervisory system. In this context, Ministry of National Education (MoNE) is the legal institution, which is responsible for the educational supervision in Turkey. According to MoNE Inspection Board Regulation which came into effect with the publishing 20.08.2017 dated, 30160 numbered T.C. Legal gazette, supervision of the institutions in the schools is carried out by the Maarif Inspectors (MoNE, 2017). For that reason, "Supervisory Guidelines" were prepared by the Inspection Board for the inspectors to use while carrying out duties. It is necessary to carry out its duties in a planned and systematic manner. One of these guidelines was "the examination of Provincial/District National Education Directorates Guidance and the Supervisory Guide Based on Legal Documents and Literature." The purpose of this research is to examine the "Provincial / District National Education Directorates Guidance and the Supervisory Guide" on the basis of legal documents and literature. It has been determined that there are some problems in ensuring the unity of implementation and standardization among the Heads of Education Inspectors, the implementation of guidance and audit principles, the auditors and the reporting of the audit results to the relevant units and persons. For this reason it may be beneficial to examine the guideline based on the literature of educational supervision and legal documents. When the literature was searched, it was found that there were no more studies on this subject. In this context, examining of the guide is important in terms of enlightening, leading and contributing to the literature. The purpose of the study is to examine the consistent and inconsistent aspects of the "Provincial / District National Education Directorates Guidance and Inspection Guide" document published by the Ministry of National Education on the basis of domestic legal documents and literature, and to develop recommendations in line with the findings.

Method: Document analysis technique, one of the qualitative data collection techniques was used in this study. The supervisory guideline was analyzed according to the stages of document review in order to guide education supervisors in auditing as a public document. The Ministry of National Education Board published 16 supervisory guidelines on its official website, which were prepared for various institutions in 2016. These guides were published in order to guide education supervisors in their inspections and to indicate principles which will be applied in the inspection process. The document of this study was one of the published ones,

Provincial / District National Education Directorates Guidance and the Supervisory Guide" In this case, the supervisory guideline, which is studied document, was examined under the main headings 1) The relation of the Provincial/District directorates of National Education Guidance and the supervisory guide with the legal documents 2) The relation of the Provincial/District directorates of National Education Guidance and the supervisory guide with the literature. The collected data was analyzed by content analysis. The main purpose in content analysis is to reach the concepts and relationships that can explain the collected data. The content analysis consists of the following stages; coding of data, finding themes, organizing codes and themes, defining and interpreting the findings. In the first stage, the guideline was examined based on legal documents in content analysis; theme, category and codes were formed. In the second stage, the guide was examined based on the literature; themes, categories and codes were formed. To strengthen understanding in the transformation of the data into findings, a percentage distribution or digitization of the data was also used. Finally, the analysis was supported and interpreted with appropriate quotations according to the themes during the use of the data. In order to ensure the validity and reliability of the research, the internal validity (credibility) of the data was ensured by expert review and colleague confirmation. In addition, regarding the examination of the guideline, the researchers, who examined the supervisory guidelines of different institutions, arranged a meeting on a specific day and time every week via live meeting tools on the internet so as to contribute to the validity and reliability. In these meetings, a competent academician who 
has publications in the field of educational science and supervision and an education supervisor participated in these meetings in order to obtain expert opinion and provide feedback. In the meetings, first of all, studies were carried out on how the guides could be examined. Afterwards, the review of the guide on the foundation of the legal basis and the literature and accordingly the content analysis was focused on the processes of creating themes, categories and codes. Similar and different aspects were emphasized by comparing the themes, categories and codes determined in the working processes. Discussions were made on the points of disagreement and meetings continued until consensus was reached. After the final meeting, they were sent to academicians who were experts in the field of study and their opinions were included in the study. The raw data of the research was stored for external reliability (confirmability).

Findings: As a result of examining the legal documents, some of the legal documents of the guideline were not updated or abolished. In addition, legislations were rapidly changed in Turkey. Although some of the statements in the guideline referred to the related documents, most of the statements did not have a legal basis. Besides, some of the statements were incomplete, inaccurate or more detailed according to the version in the legal document. Rapid change of legal basis of the relevant articles of the guideline especially made trouble for the supervisors and it caused them to fall behind in the face of changing laws and not be able to renew themselves in the face of changing laws. As a result of examining of the guide on the basis of the literature; there were deficiencies in the content of some statements in the guideline. None of the statements was referred to scientific studies. The use of some of the concepts was inconsistent with the literature or some concepts covered each other. Consequently, if the guide is to be scientific, the literature may be used.

Suggestion: Depending on the changing legal documents of the guide, it can always be kept up to date In addition to the opinions and decisions taken in the higher boards of the Ministry of National, a study board which is consisting of education supervisors related to the guide can be established in order to keep up to date. While preparing the guide, Education taking the opinions of all education stakeholders can be taken into consideration. This situation will ensure that the guide will be more adequate in terms of both quantity and quality. Legal articles related to the guide can be accessed on the internet within the scope of various regulations or the Official newspaper and directives, however, this takes much time for both supervisers and researchers, causes energy and losses. In order to minimize these losses, it may be suggested to bring together the relevant laws, regulations, and circulars of the guide to facilitate collection in a single internet address in the digital environment and delivery them to supervisors. Can be accepted as a career profession and be encouraged. A class of inspection services should be established and necessary legal arrangements should be made in this regard. Training packet guides which are explaining the steps to be followed in the inspection process and the tools to be used during inspection should be prepared by the Ministry of National Education, It may be suggested to examine much detailed study of the literature. In the guide, statements with lack of content and inconsistency related to the literature in the guide were determined. A scientific committee consisting of academicians might be established in order to prepare the guide on the basis of the literature and to ensure its control. 